\title{
Náboženství v laboratoři sociální implicitní kognice: víra $v$ automatických reakcích jako implicitní postoj a dovednost'
}

\author{
Religion in the Laboratory of Social Implicit Cognition: Belief \\ in Automatic Reactions as Implicit Attitude and Skill
}

Tomáš Hampejs

\begin{abstract}
This article straddles the border between theoretical essay and review study. It points to the methodological paradigm of experimental social psychology as a promising space for research on religious belief between the universal claims of the cognitive science of religion, with its emphasis on the evolved cognitive capacities of human behaviour, and traditional historiographic and anthropologic methods with their stress on socio-cultural context. It tries to answer some questions for meaningful reduction and experimentalization of religious belief and reflects on the possibility of measuring such belief beyond the use of questionnaires with their limit on introspection and problem of social desirability bias. It introduces experimental space as a place where new layers of contextual properties are paradoxically revealed, thanks to the reduction and decontextualization of the studied phenomena. Religiosity and religious belief therefore show to a greater extent their dependency on concrete practices and performances. The general aim of the article is to show how an experimentally based conception of the affective part of religious belief, as an implicit attitude, contributes to the de-essentialization of religious belief.
\end{abstract}

KEYWORDS religious belief, social implicit cognition, implicit attitude, experimental study of religion

\section{Náboženská víra jako předmět vědeckého zkoumání?}

Víra jako pojem: mezi vírou, přesvědčením a dưvěrou

Pojem náboženské víry v okcidentálním civilizačním okruhu pramení v širokém diskurzu křest’anství. Zde je možné nalézt víru v extrémních rozpětích významu mezi jednoduchým přesvědčením o boží existenci a například existenciálním filosoficko-teologickým postojem Sørena Kierkegaarda (2008). Ačkoliv je Kierkegaardovo dílo originální a Kierkegaardova víra odráží svého druhu normativní ideál, v zásadě v něm lze spatřovat jakýsi ideální typ protestantského pojetí náboženské praxe, jež se odvrací od „vnějších“ rituálních praktik

Sociálni studia. Katedra sociologie FSS MU, 2/2013. S. 85-114. ISSN 1214-813X.

1 Následující text vznikl v rámci projektu specifického výzkumu „Interdisciplinární přístupy v religionistice“ (IPVREL) řešeného Ústavem religionistiky FF MU v roce 2013. 
k vnitřnímu osobnímu vztahu. ${ }^{2}$ Abrahám jako muž víry, který je schopen obětovat vlastního syna na Boží př́ikaz a na základě vlastní silné osobní predispozice tento příkaz následovat, se pro Kierkegaarda stává dokonce rytî́em víry a víra skrze Kierkegaardovo dílo získává charakteristické konotace komplexního vztahu k transcendentnu, který později mimo teologii a filosofii náboženství vyjádř́ existencialismus. Pojem víra může v evropském kontextu snadno zastupovat esenci náboženství vůbec. ${ }^{3}$ Takto pojatá víra intertextově napnutá mezi křest'anskou literaturu a její po staletí probíhající artikulace je obtižně jednoznačně definovatelná a v sociálních a historických vědách usilujících o mezikulturní vědeckou analýzu se může snadno dostat do stejných problémů jako samotný pojem náboženství (viz např́íklad Smith 1998).

Je víra jev nutně spjatý s náboženstvím a je možné srovnávat existenciální elaborace veř́ících filosofu, jako byl Kierkegaard, s běžnými náboženskými postoji neevropských tradic? Můžeme pojem víry použít jako univerzální pojem při provádění např́ílad religionistických komparací? Je-li nějaký pojem diskurzivně pevně spojený s křestanskou evropskou tradicí, a jeho universalistické používání bude nejspíš vyvolávat automatické antietnocentrické reakce u většiny badatelů, pak je to právě pojem víry. Tam, kde angličtina může rozlišovat mezi faith a belief, má český jazyk v substantivu k dispozici jen jeden pojem. Faith je zde onou kierkegaardovskou vírou naplněnou existenciálním zápasem, zatímco belief může být neutrální pojem označující mentální propoziční vztah mezi subjektem a předmětem, tj. určité přesvědčení o něčem. Tam, kde si angličtina může dovolit jednoduchou větu: „Součástí faith je celá řada beliefs“, je třeba v českém jazyce opsat: „Víra (jako komplexní náboženský postoj) obsahuje celou řadu přesvědčení. “" Belief však nejde jednoduše ztotožnit s přesvědčeními, jak ukazuje už např́klad překlad Tylorovy definice náboženství jako „víry (belief) v nadpřirozené bytosti“, která by v jednom z možných přepisů „přesvědčení o nadpřirozených bytostech“" ztratila podstatnou porci významu. České slovo „přesvědčení“ totiž postrádá klíčovou rovinu, již anglické belief obsahuje, totiž důvěru. ${ }^{5}$ Překladatelská hra mezi emickými významy, jež musí být nakonec nutně zakotvena viči specifické diskurzivní tradici, ze které je překlad veden, však může být naštěstí převedena do etické roviny badatelsky definovaných pojmů.

2 To nahrává atmosféře tohoto textu, který bude náboženskou víru psychologizovat. Je ale nutné připomenout, že kulturně historický koncept víry se nejen pro Kierkegaarda touto vnitřní dispozicí samozřejmě nevyčerpává, když může být považována např́klad za zázrak s ohledem na její tematizaci jako důsledku Boží milosti (Wisdo 1987). Př́ípadná epistemologická redukce (psychologizace) Kierkegaarda slouží v zásadě jako ilustrace, volba Kierkegaarda jako př́ikladu je arbitrární. Tento text nemá žádné ambice s ohledem na rozměry víry v kontextu filosofie náboženství.

3 Víra může být považována za něco bytostně náboženského. V psychologii náboženství to ukazuje např́iklad tzv. „,teorie vývoje víry“ (Hart 2009) odkazující k jednomu z mnoha propojení (vývojové) psychologie a křest’anské protestantské teologie. S tímto pojetím touto studií neprímo polemizuji, když se v rámci tradice kognitivní religionistiky ptám po jejích psychologických mechanismech.

4 Cizojazyčné citace v textu uvádím ve vlastním překladu.

5 Belief definuje Merriam-Webster mimo jiné pomocí slova trust, tj. důvěra. 
Tomáš Hampejs: Náboženství v laboratoři sociální implicitní kognice...

\section{Přislušnost k sociální skupině, osobní přesvědčení o skutečnosti a dispozice k jednání}

Zde je možné uchopit pojem ve dvou až třech ohledech. Na jedné straně podle konkrétního obsahu, tj. přesvědčení $o$ něčem. Taková víra může být snadno hranicí ustavující sociální skupinu. Zde jsou prototypem specifická „vyznání víry“ nejen jasně deklarující předměty víry, ale často i symbolicky vyjadřující prŕíslušnost ke specifické náboženské skupině. Na druhé straně lze pohlížet na víru jako na vztah důvěry nezávislý na konkrétních vyjádřených obsazích a projevovaný v jednání na základě postoje $k$ něčemu (srovnej encyklopedické heslo „Faith“ [Helsel 2009]). Tyto póly lze dále spojit s dalšími dualitami, jako je třeba racionalita a emocionalita. Pomineme-li nyní jednu údajně podstatnou vlastnost náboženské víry, tj. že je považována za prototyp přesvědčení bez evidence (např. Dawkins 2006), je víra jako set určitých přesvědčení, respektive jako „vyznání víry“, spojitelná s určitou sociální sebe-deklarací a můžeme ji snadno spojit $\mathrm{s}$ racionálním aktem přihlášení se $\mathrm{k}$ hodnotám dané sociální skupiny. Oproti tomu víra jako důvěra se zdá být především emocionálním nebo volním postojem. Ideálně typickou situaci samozřejmě komplikuje skutečnost, že již zmíněný akt „vyznání víry“ může samozřejmě obsahovat a nejspíše i obsahuje oba typy.

Filosofie náboženství spíše než o typech mluví o třech složkách víry - kognitivní (víra jako vědění), afektivní (víra jako důvěra) a volní (víra jako vůle $\mathrm{k}$ činu) - a víru napíná do celé řady modelů (Bishop 2010). ${ }^{6}$ Osou všech se však nakonec zdá být rozlišení propozičního vědění, důvěry a př́ípadně schopnosti na základě předchozích dvou dispozic konat. Výčet podstatných vlastností náboženské víry by stěží mohl být úplný, kdybychom nezmínili prvek, který je v mnohém kritériem odlišujícím náboženskou víru od běžných přesvědčení vůbec, tj. otázku evidence skutečností, ke kterým jsou přesvědčení směrována. Zde se víra dostává do své pro Evropu klasické kontrapozice s rozumem. Z širokých dějin tohoto vztahu mne v tomto textu zajímá Anselmovo „věŕím, abych rozuměl“, které lze snadno spojit s pragmatismem Williama Jamese a jeho přednáškou „Will to believe“ (1896), a k němuž lze vztáhnout i Kierkegaardova Abraháma jako rytíre víry. Zákruty filosofie náboženství a její snahy pečlivě analyticky zpracovat odlišnost běžných přesvědčení od náboženské víry chci v tomto textu programově omezit na Jamesovo přesvědčení, ve kterém je víra dispozice k praktickému uvažování7 a jednání př̀i vědomém rozpoznávání nedostatku samostatné empirické existence objekti̊, k nimž směřuje. Extrémem je v tomto ohledu Kierkegaardův důraz na víru jako „vášnivou objektivní nejistotu“ (Kierkegaard 1846 [1968]: 180), kde teprve vědomá akceptace neevidence umožňuje onen „skok víry“. Víra je pro Kierkegaarda plná angažovanost vưči určitým skutečnostem, za vědomí jejich objektivní nedoložitelnosti (Bishop 2010). James i Kierkegaard se oba pohybují v tradici, která zdůrazňuje individuální prostor náboženské zkušenosti. Př́ípadné akademické studium náboženství - zejména sociální psychologie se v této perspektivě musí vyrovnat s klasickou problematickou dualitou, tj. s oddělováním vnější (sociální) a vnitřní (autentické) náboženskosti.

$6 \quad$ Kierkagaardovo pojetí zde přestavuje komplexní model víry zahrnující všechny tři složky, tj. jak vědění-přesvědčení o určitých skutečnostech, tak důvěru v ně, stejně jako schopnost podle nich jednat bez evidence (doxastic venture model).

7 „Practical reasoning“; více viz Bishop (2010). 


\section{Mezi vnější a vnitřní náboženskostí: chování, myšlení nebo cítění?}

V psychologii náboženství zanechala tato dualita stopu např́íklad v Allportově rozdělení náboženskosti na vnitřní (intrinsic) a vnější (extrinsic) religiozitu (Allport a Ross 1967). ${ }^{8}$ A Allportovo pojetí, rozpracované například v dodnes používaném Gorsuchově testu náboženské orientace 9 (Gorsuch a McPherson 1989), je možné považovat za další výchozí bod tohoto textu. Představuje psychologii náboženství, která v mnohém pracuje s vírou v jejích emických konotacích. To není nejspíš problém, pokud zkoumáme protestantské křest'anství, ale když vyjdeme mimo jeho rámec, ukáže se tento koncept, oddělující vnější a vnitřní prvky do dvou typů, jako problematický. Není to však kvůli jejich dualitě, ale kvůli nadřazení jednoho typu nad druhý. ${ }^{10}$ Psychologie náboženství v tomto ohledu nemůže uniknout problémům spjatým s každým akademickým pojetím náboženství, tj. problémům konstrukce analytických kategorií.

Sociální a humanitní vědy zde zápasí s potížemi, které př́írodní vědy neznají, tj. s nesnázemi při práci s jevy silně kotvenými emickým diskurzem. Př́ípadný etnocentrický charakter určité psychologie náboženství však není hlavním motivem, který bych chtěl na Allportově konceptu religiozity zdůraznit. $Z$ hlediska vědecké metody vězí Gorsuchův dotazník pevně v tradici sociálních věd, které se snaží postihnout běžným smyslům skrytý svět subjektu, a to v zásadě tím nejpřirozenějším lidským způsobem, tj. dotázáním se. I když nejde ztotožnit běžnou lidskou komunikaci s přes století dlouhou tradicí vědecké „,dotazovací“ metodologie, v obou př́padech se jedná o zpř́ítomňování neviditelných dispozic a stavů pomocí jazyka, introspekce a sociální situace dotazování. Víra je zde v mnohém především sofistikovaným odrazem toho, jak o ni lidé přemýšlejí, at' už ve vlastních nebo badatelem navržených kategoriích, a konkrétní situace. Taková víra je tedy v mnohém otázkou reflexivity lidského jednání a případné badatelské schopnosti postihnout za touto reflexí skutečný svět.

Víra může být ale také kladena jako odraz chování. Vrátíme-li se např́íklad ke Kierkegaardovu Abrahámovi, můžeme si povšimnout, že jeho víru je možné odečítat ze specifického jednání. Abrahámova víra získává svo̊j silný náboj především z kontrastů situace-příběhu, ze kterého je odečítána. Na druhou stranu takto konstruovaná víra získává samostatnou mocnost v podobě specifické osobní dispozice, jež je kladena jako zdroj sledovaného jednání. Existuje však tato dispozice jako kauzální mocnost i mimo reflexivní výpovědi o ní? $\mathrm{V}$ tomto smyslu

8 Vnější náboženskost je chápána v zásadě jako sociální př́ílušnost, jejím typickým znakem je například „nedělní rodinná návštěva kostela“, kterou může ze sociálních důvodů vykazovat i „,vnitřní“ ateista; vnitřní náboženskost je pojímána jako osobní přesvědčení o pravdivosti náboženských skutečností a s ním spjatá angažovanost.

9 Ačkoliv Allport a Gorsuch pracují s religiozitou/náboženskostí, jejich koncept vnitřní náboženskosti je snadno ztotožnitelný s vírou jako vnitřní dispozicí. Intrinsic lze překládat nejen jako vnitřní, ale i jako pravá, skutečná nebo podstatná. Nejde tedy jen o rozlišení místa projevu, ale i o určité hodnocení, která náboženskost je více u podstaty věci.

10 Zejména pokud intrinsic/vnitřní konotuje i význam ,pravý“. Nadřazení vnitřních postojů vůči vnějším projevům vyvolává otázky i u samotných psychologů (Flere a Lavrič 2008), kteří se v článku „Is intrinsic religious orientation a culturally specific American Protestant concept? The fusion of intrinsic and extrinsic religious orientation among non-Protestants" ptají, zda není Allportova vnitřní religiozita skutečně odrazem hlavně protestantského křest’anství. 
je akademická problematizace náboženské víry na stejné úrovni se všemi mentálními a sociálními jevy, jež nelze poznávat mimo jejich důsledky, respektive performanci. ${ }^{11}$ Sociologický či psychologický dotazník jsou v tomto ohledu jen specifické umělé situace, ve kterých je projev hledaných vnitřních dispozic vázán na komunikační médium metody.

\section{Možnosti zkoumání a sběru dat: od pozorování v prirrozeném prostředí k experimentu}

Badatel má z metodologického hlediska tři možnosti - bud’ vyjde z pozorování a výpovědí subjektů a pojmy nechá zakotvené primárně emickým diskurzem; to odpovídá kvalitativnímu sběru dat. Nebo v př́padě sociologického či psychologického výzkumu založeného na dotazování vytvoří prostor pro kontrolované odpovídání (vyplnění dotazníku), který je opřen jak o emický (respondent musí otázkám rozumět), tak o etický diskurz (dotazník může zkoumat víru, aniž se slovo víra $\mathrm{v}$ dotazníku objeví) $\mathrm{v}$ podobě operacionalizace, to odpovídá např́iklad sociologickému kvantitativnímu výzkumu. Třetí možností je behaviorální experimentální výzkum, který vytvář́i umělé prostředí pro pozorování, tj. kontrolovanou performanci. Používá hlavně vlastní etický diskurz, a je proto velmi závislý na teoretickém ukotvení. $\mathrm{Na}$ všechny tři metodologické póly se však lze dívat spojitě v rámci kontinua metodologického oddělování jevu od jeho přirozeného prostředí.

Je-li jedním z cílů tohoto textu obhajoba psychologické kognitivní laboratoře jako přirozené a nikoli extrémní metody pro poznávání náboženských jevů, pak jeden z argumentů vychází ze specifické performativity všech vědeckých metod, tj. nutnosti data vytvářet, oproti jejich „nalézáni“. Jevy jsou vždy inferovány z konkrétního dění a z obecných znalostí o povaze tohoto dění1 ${ }^{2}$. Metodologické rozdíly mezi etnografickým rozhovorem, sociopsychologickým dotazníkem a sociálně psychologickým experimentem leží kromě problému jazyka, kterým je jev popisován, právě v miře kontroly performance a její distribucí mezi badatele a subjekt. Je-li zúčastněné pozorování metodou prototypickou pro snahu postihnout jev v jeho přirozených podmínkách, pak experiment symbolizuje maximální badatelskou kontrolu založenou na redukci a přenesení jevu z jeho vlastních podmínek do podmínek kontrolovaných (a tedy umělých). V sociálních vědách je však redukce a možnost přenést jev mimo jeho přirozený výskyt chápána jako obtížně prèekonatelný problém. Můžeme víru zkoumanou v laboratoři ještě označit za víru? Je možné vést dialog mezi historicko-interpretativní analýzou biblických vyprávění, kierkegaardovskou filosofií a psychologickým výzkumem?

11 Koncept performance zde použivám jako výraz pro dění, dělání v určité konkrétní sociální situaci. Nejde mi o performanci jako představení, ale o performanci jako koncept odkazující ke zcela konkrétnímu jednání a chování. Pohybuji se v rámci vytýčeném performační teorií rituálu (Grimes 2004), s tím rozdílem, že performanci neomezuji na rituál jako takový a chci se vyhnout rozlišování mezi teorií performance a teorií rituální praxe (Bell 1992). Peformance je pro mne pojem označující činnost včetně jejího kontextu, která umožňuje projevení vlastnosti určitého systému. Jsem tak možná svým pojetím blíže pojetí rituální praxe, nicméně protože tento text má metodologické ambice ukázat souvislosti mezi experimentem a rituálem jako prostorem pro projev náboženské víry, zvolil jsem termín performance, nebot’ v něm zřetelněji zaznívá role situačního kontextu.

12 V tomto smyslu se například můžeme ptát, kde je v Bibli náboženství. Nachází se př́mo v ní, nebo jen v mysli některých jejích čtenářů? A jakým způsobem ho vlastně může zpředmětnit výzkumník? 
Pokud budeme míru kontroly a separace jevu od jeho přirozených podmínek chápat právě spíše jako kontinuum než jako úplně oddělené světy, tj. budeme všechny tři vědecké pozice integrovat do mezioborových teoretických rámců, pak se domnívám, že ano. Problematičnost zkoumání náboženské víry, a v zásadě všech jevů spjatých s vnitřním životem subjektu, spočívá zejména $\mathrm{v}$ jejich př́ímé nepozorovatelnosti. Není ale př́ímá nepozorovatelnost těchto jevi̊ vlastní všem třem metodologickým pozicím, respektive i každodenní zkušenosti? Jak ví samotní věrící, že věří? Spolu s Jamesem předpokládám, že zdánlivě teologický problém má svoji pragmatickou rovinu v pozorovatelných evidencích (např́klad „mám důvěru v modlitbu“, „modlitba má pro mne pozorovatelný účinek“). Samotný Gorsuchův dotazník náboženské orientace a v zásadě všechna dotazníková měření rozkládají abstraktní koncepty na jednotlivé složky, které předkládají respondentům k porovnání s jejich osobními evidencemi. Náboženskost je zde pak měřena jako složený postoj ke konkrétním vědomým dílčím skutečnostem (viz např́íklad Francis [1989] s ohledem na křestanskou víru). Postoj analyzovaný jako sebereflektivní vědění má však svá zásadní úskalí.

\section{Za hranice osobní zkušenosti, sociální sebedeklarace i vědomého přesvědčení}

Klíčovým problematickým rysem dotazujících se metod je jejich závislost na reflexivitě respondentů, tj. jejich schopnosti přenést se pomocí virtuálních situací předkládaných $\mathrm{v}$ otázkách $\mathrm{k}$ relevantním jevům $\mathrm{v}$ osobní zkušenosti. Je-li navíc snaha sledovaný jev měřit, musí často respondent vlastní zkušenost i kvantitativně hodnotit - zpravidla pomocí stupnice odpovědí Likertovy škály. ${ }^{13}$ Jak moc se tato performance liší od Abrahámova dilematu, který se stal odrazovým můstkem pro Kierkegaardovo pojetí víry! Reflexivní povaha dotazníkové performance se výborně hodí $\mathrm{k}$ testování víry jako propoziční víry ve specifické obsahy. Škála propoziční postojové odpovědi postihuje i míru postoje mezi dvěma pozicemi, a můžeme tedy hovořit o tom, „nakolik“ někdo věrí, že Ježíš Kristus je jeho osobní spasitel. Ale deklarativní podoba odpovědí vykazuje slabinu všech na reflexivitě založených metod, tj. zkreslení dané sociální situací a povahou performance, ve které má respondent tendenci přizpůsobovat své odpovědi obrazu preferovanému v očích předpokládaného publika. Sociální psychologie nazývá tento problém zkreslením sebeprezentace (social desirability bias). Při vyhodnocování abrahámovské situace by se sociální psycholog mohl ptát, zda přítomnost Boží ovlivňuje Abrahámovo rozhodování (odpovídání, performanci), ${ }^{14}$ respektive jak by se lišila Abrahámova reakce, kdyby se ho někdo den před tím na trhu zeptal, co udělá, když mu Bůh ${ }^{15}$

13 „Na stupnici od 1 do 5 , kde 1 je velmi nesouhlasím a 5 velmi souhlasím, zakroužkujte pozici odpovídající vašemu postoji“ (více viz například Coolican 2009: 179-181).

14 Koncept sebeprezentace můžeme snadno rozššrit mimo dotazník směrem ke každodennímu životu pojímanému jako hraní rolí (Goffman 1999). Mezi praktickým metodologickým pojetím „zkreslení“ a sociologickým chápáním každodenního života jako hraní rolí je ale samozřejmě rozdíl; tak jako mezi teorií situačních faktorů jednání a obecné teorie jednání. Sociální psychologie nečiní z performance a dramaturgického jazyka ústřední diskurz.

15 V textu označuji slovem „Bůh“ jediného boha monoteistických náboženství, slovem „bůh“s malým počátečním písmenem pak obecný koncept nadliské bytosti. 
prrikáže obětovat svého jediného syna. ${ }^{16}$ Badatel analyzující Abrahámovy odpovědi/činy by tu čelil jak problému hranic Abrahámovy introspekce, tak sebeprezentace. ${ }^{17}$

Tyto dva faktory se objevují tím více, čím se otázka vzdaluje konkrétní běžné realitě a její fakticky (empiricky) postižitelné podobě a dotýká se jevů, které jsou pro subjekt samotný jen nepř́mo odvoditelné. Otázka „Kolikrát týdně navštěvujete bohoslužby?“ je jiné povahy, než otázka „Jak silná je vaše víra?“, nebo „Co byste dělal v této hypotetické situaci?“. Problémy hranic introspekce se zdají být v prostoru dotazovacích metod takřka neřešitelné, proto se všechny metody sběru dat snaží spiše ovlivnit důvěru v získanou empirii, než poskytovat respondentům možnosti, jak rozšírit vnímání sebe sama. $\mathrm{V}$ tomto smyslu existuje v sociální psychologii tradice tzv. nepř́mých metod dotazování, které se snaží vyhnout problému sebeprezentace tak, že staví respondenta do situace, kde je obtížné odhadnout spojení odpovědí se specifickým sebeobrazem (viz např́klad Fisher 1993), respektive účel výzkumu.$^{18} \mathrm{O}$ to více je pak ale měřený konstrukt konstruktem badatele a jeho teoretické pozice. Chceme zkoumat víru jako sociální deklaraci, a nebo jako osobní postoj k náboženským skutečnostem? Allportova konceptualizace, která zkouší obojí uchopit $\mathrm{v}$ rámci dvou nezávislých škál, je př́íladem teoretické pozice zatížené specifickým emickým pojetím víry především tím, že předpokládá jejich nezávislost. ${ }^{19}$

\section{Bohové v performanci a aura "faktičnosti"}

S ohledem na náboženskou víru je samozřejmě důležité, zda ji chceme ,jen“ měřit, nebo jí chceme lépe porozumět. Proto klíčovou hranicí pro porozumění viře jako případné skutečné kauzální dispozici $\mathrm{k}$ jednání bude právě ona hranice introspekce. Protože je současná technologie čtení myšlenek jen na úrovni detektoru lži, zbývá pokusit se metodicky uchopit náboženskou víru tam, kde se skutečně přirozeně objevuje, tj. přímo v chování. Zde musíme vycházet $\mathrm{z}$ předpokladu, že víra jako dispozice $\mathrm{k}$ jednání není jen záležitostí extrémních životních situací, jakou si vybral třeba Kierkegaard, ale že ji lze objevit na Jamesově úrovni „praktického myšlení“. Kierkegaardův príklad Abraháma jako muže víry v sobě s ohledem na „objektivní nejistotu“ obsahuje určitý paradox, který Kierkegaard asi nezamýšlel.

16 Tato ilustrace dovedená do absurdna měřením kierkegaardovské víry by mohla znít: „Kdyby Vám Bůh přikázal obětovat jediného syna, neváhal byste a jeho př́kaz byste poslechl? Vyznačte Váš postoj na škále $1-5$, kde 1 odpovídá velmi nesouhlasím a 5 rozhodně souhlasím.“

17 Kde by cílové publikum mohlo být minimálně trojí - Abrahám sám, dotazující se badatel a samozřejmě Bůh.

18 Většina dnešních psychologických výzkumů se tím či oním způsobem snaží vyhnout prezentačnímu zkreslení zakrytím účelů výzkumu. Existují však příklady výzkumů, které uživají přímou manipulaci postoje respodenta pomocí klamu. Tzv. metoda „bogus pipe line“ pracuje s předpokladem, že když si respondent bude myslet, že své myšlenky nemůže skrýt, respektive upravit, bude mít větší tendenci odpovídat podle svého skutečného přesvědčení. Sigall a Page (1971) zkusili napojit respondenty odpovídající otázky po rasových stereotypech na falešný detektor lži. Zjistili, že účastníci napojení na detektor vykazují výrazně silnější rasové stereotypy než kontrolní skupina.

19 Nezávislost, kterou bychom mohli shrnout jako nezávislost víry a rituálu, či ještě obecněji myšlení a konání. 
Je-li náboženská víra charakteristická zejména nedostatkem evidence, ${ }^{20}$ pak Starý zákon, ve kterém Bůh běžně s klíčovými osobami promlouvá a poskytuje jim tak svoji těžko diskutovatelnou evidenci, nelze bud' brát př́iliš vážně, nebo musíme koncept víry značně rozšíritit. Z toho můžeme odvozovat, že ve Starém zákoně, ale i v Jamesově pragmatismu, ${ }^{21}$ je klíčovou složkou víry spíše ona specifická forma osobního vztahu k náboženským faktům, než jejich pravdivost či závislost na konkrétní evidenci. $Z$ hlediska možné metody, která by mohla zkoumat takový typ víry, se můžeme nechat vést intuicí přítomnou u Williama Jamese, k níž odkazuje i Clifford Geertz ve své slavné definici náboženství přisuzující náboženským symbolů „auru faktičnosti“, zejména v rituálu. Bohové pro Geertze vstupují do lidmi vnímatelné roviny především v konkrétních aktech, respektive performancích (Geertz 1973: 112-113). Musí to však být nutně rituální performance?

\section{Náboženská zkušenost v každodenním životě: interakce vědomého a nevědomého}

Budeme-li spolu s kognitivní vědou o náboženství (viz Pyysiäinen 2013) předpokládat, že kognitivní procesy spjaté s náboženstvím nevyžadují žádné speciální mechanismy, nýbrž využívají standardní kognitivní výbavu, jež je v zásadě universální (například Boyer 2001), a že náboženskou víru lze uchopit jako vnitřní osobní dispozici, pak by mělo být teoreticky možné přenést a studovat nábožensky relevantní jevy i v laboratorních performancích, tj. experimentech pomocí metod, jež umí s touto „výbavou“ pracovat. Pro Geertze i Jamese jsou bohové v performanci otázkou náboženské zkušenosti, tj. vědomého světa subjektu; ten se může zdát vědcům stejně obtižně př́stupný v laboratoři jako kdekoliv jinde. Na druhou stranu s rozvojem kognitivní psychologie a kognitivních věd obecně můžeme dnes mluvit o několika rozměrech náboženské zkušenosti (Cohen, Hill, Shariff a Rozin 2008). Tam, kde kognitivní věda o náboženství proslula postulací nevědomých evolučně vyvinutých kognitivních mechanismů, které jsou na vědomém světě s jeho kulturními variacemi nezávislé a jsou jeho podkladem, ${ }^{22}$ empirická psychologie náboženství usiluje o pochopení interakce vědomých a nevědomých rovin sociálního jednání. S ohledem na náboženskou víru $\mathrm{v}$ jejích komplexních konotacích a na kritiku „standardního modelu náboženského chování a myšlení“ (Jensen 2009 vůči Boyer 2005) reprezentovaného evolučně orientovanou kognitivní vědou o náboženství se už od počátku objevuje požadavek doplnit kognitivní studium náboženství v podobě slavných Boyerových intuitivních ontologií (Boyer 1994) o afektivní mechanismy

20 Jak o ní mluví např́iklad tzv. „,nový atheismus“ (viz např́íklad Dawkins 2006: 28).

21 A možná v náboženství obecně, zưstaneme-li u jednoduché Tylorovy definice „,víry v nadpřirozené bytosti“ a nebudeme-li studovat euroamerickou civilizaci v moderní sekulární fázi s jejím dialogem mezi náboženstvím a ateismem.

22 Kognitivní religionistika může v tomto ohledu se svojí nedůvěrou ve validitu subjektivních výpovědí působit prřmo jako protiklad fenomenologických přístupů. „Většina [nábožensky] relevantní mentální výbavy není vědomě přístupná. Explicitně držená vědomě přístupná přesvědčení, stejně jako v jiných doménách kognice, reprezentují jen fragmenty relevantních procesů. Experimentální testy ukazují, že to, v co lidé skutečně věří, se často liší od toho, v co si myslí, že věří. Proto teologie, explicitní dogmata a akademické interpretace náboženství nemohou být vnímány jako spolehlivý popis obsahů, nebo prř́čin lidských přesvědčeni““ (Boyer 2003: 119). 
zodpovědné právě za angažovanou víru (Pyysiäinen 2003). ${ }^{23}$ Smysluplnost Boyerova programu předpokládajícího určitou přirozenou formu náboženskosti uvnitř každé náboženské tradice dokládají např́klad experimenty Justina Barretta a Franka Keila (Barrett a Keil 1996). Ty potvrzují rozlišitelnost dvou schémat náboženskosti i u praktikujících křest’anů - př́slušníků „vyspělé“ teologické tradice: explicitního - teologicky korektního - a implicitního - přirozeného, vycházejícího z vlastností lidské kognice zpracovávající jevy antropocentrickým způsobem. Jakkoliv Boyerův program umístující bohy, či přesněji jejich mentální reprezentace, do tzv. minimálně kontraintuitivních konceptů (Barrett 2000) dokázal vysvětlit univerzálně přítomné představy o nadlidských činitelích, ještě nenabídl uspokojující model náboženské zkušenosti, respektive víry, s jakou pracuje Kierkegaard nebo James. Je samožrejmě možné odmítnout přinejmenším kierkegaardovskou víru jako teologický konstrukt, který se „skutečnou každodenní“ náboženskostí nemá př́liš společného. Nicméně otázka víry, respektive konkrétní důvěry v nadlidské činitele, oproti schopnosti je myslet či si je pamatovat, realizovaná například diskusí o rozdílech mezi Myšákem Mickeyem (Atran 2002), Santa Clausem (Barrett 2008), Diem a „skutečnými““ bohy, ve které někdo konkrétní věří (Gervais a Henrich 2010), se stala symbolem pro hledání rozšířených modelů nábožensky relevantní kognice zahrnující nejen ty nejzákladnější mentální mechanismy v podobě konceptuálních forem myšlení, ale i vliv socio-kulturního kontextu. Východiskem by mohly být modely, které epistemologicky rozdělují mysl na dvě části.

\section{Náboženskost v rozdělené mysli: k sociální implicitní kognici}

Pyysiäinen je pak jedním z prvních, kteří napnou náboženství do teorií duálně zpracovávající kognice (2004), jež smysluplně propojuje svět vědomé zkušenosti s jeho kognitivním podkladem. ${ }^{24}$ Koncept dvou mentálních systémů, konstruovaný často v podobě protikladů jako intuitivní a explicitní (Pyysiäinen 2004), intuitivní a reflexivní (Mercier a Sperber 2009;

23 Napětí mezi Boyerovými intuitivními ontologiemi a Pyysiäninenovou snahou doplnit program kognitivní vědy o náboženství o další úrovně kognice lze shrnout jako napětí mezi vysvětlením přenosu náboženských představ na základě zapamatování oproti afektivním postojům a motivanému angažovanému chování $\mathrm{k}$ těmto představám. Boyer si je odlišnosti víry a paměti sice vědom, ale jeho plnou pozornost získává hlavně pamět' v kontextu Sperberovy epidemiologie reprezentací (Sperber 1996) v rámci hledání tzv. kulturních atraktorů, tj. kognitivních forem (mentálních mechanismů) vysvětlující stálost určitých reprezentací v procesu jejich přenosu i např́č kulturní různorodostí.

24 Pyysiäinen ve svém pojetí duální kognice prrímo mluví o studiu nábožensky relevantní kognice pomocí sociální psychologie: „,[...] idea intuitivních ontologií by měla korelovat s myšlenkou automatických a implicitních procesů $v$ sociálnich kognitivních vědách a neuropsychologii“ (Pyysiäinen 2004: 124, kurzíva TH). Doména intuitivních systémů je pro něj jak prostorem vrozených kognitivních limitů, tak intuitivních postojů založených na implicitním učení. Tyto systémy, jakkoliv pravděpodobně pracují odděleně, se tak v konkrétních situacích překrývají, tj. lidské jednání je výsledkem jejich společného působení. „Komplexní mentální procesy, které studují sociální vědy, stěží mohou být jen automatické nebo jen kontrolované; spíše jsou výsledkem vlastností obou systémů“" (Pyysiäinen 2004: 134). 
Sperber 1997), zkušenostní a racionální (Epstein 1994), pomalé a rychlé (Kahneman 2011) či prostě „Systém 1“ a „Systém 2“ (Mercier a Sperber 2009), se tak stává téměř standardní teoretickou optikou pro uchopování lidské kognice v její celistvosti.

Uvažování „Systému 1“ je rychlé, automatické a převážně nevědomé; spoléhá se na rychlou
a šetrnou heuristiku (Gigerenzer a Todd 1999) a nabízí patrně bez úsilí závěry, které jsou obec-
ně adekvátní ve většině prostředí, ale mohou být chybné např́iklad v experimentálních situacích
vytvořených k testování limitů schopnosti lidského uvažování. Uvažování „Systému 2“ je pomalé,
vědomě kontrolované a vyžaduje úsilí, nicméně umožňuje následovat normativní pravidla a pře-
konat nedostatky „Systému 1“ (Evans a Over 1996).

(Mercier a Sperber 2009: 119)

Dualita mysli, proslavená Sigmundem Freudem v podobě vědomého a nevědomého, se dá v sociální implicitní kognici ${ }^{25}$ operacionalizovat opatrněji i praktičtěji jako vztah kontrolovaných a nekontrolovaných-automatických procesů (Payne a Gawronski 2010: 2). Paradigma sociální implicitní kognice je totiž spíše metodologické než epistemologické a je vystavěno v zásadě na prakticky orientované snaze uchopit relevantní sociální jevy za rámec sebereflektivních výpovědí s jejich hranicemi introspekce a zkreslením sebeprezentace. Tj. tam, kde Freud společně $\mathrm{s}$ Boyerem vycházejí $\mathrm{z}$ nevědomého, ${ }^{26}$ je počáteční bod sociální implicitní kognice, která se snaží překročit rubikon nepř́mých dotazníkových měření s ohledem na problém zkreslení v rámci sebeprezentace. ${ }^{27}$

Laboratoř sociální implicitní kognice je nicméně unikátní především svými specifickými metodami, které slibují schopnost studovat ty složky náboženské víry, které jsou za hranicí běžné introspekce. Oproti jiným metodám mají nepřímé metody sociální psychologie studující implicitní kognici schopnost „prristihnout bohy“ prrímo v oné performanci, ve které odrážejí svojí auru faktičnosti - přinejmenším v rozměrech, kterých si všímá už William James, když tvrdí, že víru je třeba vyvolat, tj. není možné ji volním způsobem vytvořit (James 1896, podle Bishop 2010). Tematizace situace (specifického podnětu) jako aktivátoru kognitivní dispozice je jedním ze stěžejních témat sociální kognitivní psychologie. Jamesovo pragmatické pojetí náboženské víry jako působící síly stěží může najít adekvátnější vědecké paradigma než takové, které jí dokáže dát měřitelný rozměr na behaviorální úrovni. Spočívá-li problém vysvětlení náboženské víry v něčem jiném než v intepretaci jejích propozičních částí, tedy máme-li vzít $\mathrm{v}$ potaz její roli jako specifické dispozice $\mathrm{k}$ myšlení a jednání, musíme ji studovat přímo $\mathrm{v}$ jednání a samotné jednání rozložit na jeho stavební části. Atributy implicitního, automatického a nevědomého mohou vyvolávat dojem psychologického determinismu a redukce Kierkegaardovy existenciální filosofické poezie na mentální mechanismy může na někoho působit jako pokus o překlad eseje o estetických kvalitách hudby do neurofyzikální rovnice vnímání zvuku. Máme-li ale lépe porozumět

25 Tento termín budu v textu používat jak jako oblast lidské kognice, tak jako metodologický prostor s ní související.

26 Byt' oba samožrejmě dost rozdílným způsobem.

27 Tento problém je v sociální psychologii spojený zejména se zkoumáním (nejen) rasových stereotypů (viz např́klad Dovidio, Kawakami a Gaertner 2002). 
náboženské zkušenosti $\mathrm{v}$ její komplexitě, musíme především porozumět subjektivitě. To naštěstí neznamená, že jsme odkázáni na interpretativní fenomenologickou tradici kvalitativního výzkumu. O subjektu, respektive mysli, má rozhodně mnoho co ř́ci kognitivní věda s její teoreticko-reduktivní behaviorální perspektivou třetí osoby.

\title{
Implicitní a explicitní vs. vědomé a nevědomé: víra v automatických reakcích
}

\author{
Paradigma měření reakčního času a vyvozované mentální procesy
}

Sociální implicitní kognice patří tedy do kognitivní, respektive sociální psychologie, kde je široce chápána jako implicitní/automatické/nevědomé procesy (pamět', vnímání, rozhodování) zakládající sociální chování (Payne a Gawronski 2010: 1). K jejím charakteristickým vlastnostem patř́i studium souvstažnosti s explicitními (vědomými) kognitivními procesy a používání nových nepř́ímých ${ }^{28}$ metod měření, jako je např́klad implicitní asociační test (Greenwald, McGhee a Schwartz 1998). „Implicitní“ v názvu testu odkazuje jak k tomu, co je měřeno (tj. implicitní procesy), tak ke způsobu, kterým se měření odehrává (tj. nepř́imým, nezjevným způsobem). Jakkoliv může nepř́má metoda zkoumání pracovat i s dotazníkem, vlajkovou lodí sociální implicitní kognice jsou experimentální metody, při kterých je měřen reakční čas. Podstatou vědeckého experimentu v užším smyslu slova je kontrolované prostředí s nezávislou (vstupní) a závislou (měřenou) proměnnou. Nutnou součástí experimentálního designu je vytvoření performance, ve které je možné měřit kontrast mezi těmito sledovanými proměnnými. Paradigma měřní reakčního času v sobě nese základní předpoklad, že rozdíly v reakčních časech indikují rozdíly v mentálních procesech. Protože typickou snahou experimentální metody je sledované jevy co nejvíce izolovat, většina laboratorních úloh, které participanti řeší, je sama o sobě triviální - úlohy musí být řešitelné více méně „automaticky“ a účastníci mají většinou instrukci řešit úlohy, jak nejrychleji mohou. Smysluplnost performance se ukazuje až v kontrastu, který se objevuje po celé řadě opakování. Rozdíly reakčního času, ze kterého jsou změny v mentálních procesech odvozovány, se pohybují v řádu stovek milisekund, proto laboratoř ve fyzickém slova smyslu tvoří technologie schopné kontrolovaně prezentovat podněty a okamžitě zaznamenávat reakce, tj. osobní počítače ${ }^{29}$ Počítačově prezentované úlohy, které na základě jemných změn v opakování jednoduchých úloh nechávají projevit předpokládané vnitřní dispozice, jsou ale samožrejmě jen součástí komplexnějších designů. Experimenty lze v tomto ohledu rozdělit na dva typy. Psychologické laboratoře se na jedné straně snaží vytvořit maximálně kontrolované prostředí,

28 Jeden z matoucích momentů implicitní sociální kognice může být otázka, zda „implicitní“ odkazuje ke způsobu měření (implicitní měření), nebo popisuje měřený konstrukt (například implicitní postoj). De Houwer (Moors, Spruyt a De Houwer 2010) navrhuje konvenci používat atribut ,implicitní“ k popisu konstruktu, zatímco měření popisovat jako „nepř́ímé“ (indirect).

29 Jakkoliv to může znít paradoxně třeba terénním výzkumníkům zvyklým jen na diktafon, právě počítače činí metodologii poměrně př́stupnou a laboratoř se tak může skládat $\mathrm{z}$ jednoho notebooku. 
ve kterém to, co je měřeno, je experimentátorem vyvoláno. Př́kladem takových experimentů jsou všechny úlohy, ve kterých si účastníci nejdřive mají něco zapamatovat a později je měřena jejich schopnost si dané podněty vybavit. Na druhé straně se sociální psychologie, stejně jako většina věd zkoumající náboženství, snaží zkoumat dispozice, které pocházejí z předchozí socializační zkušenosti a nejsou experimentátorem přímo vyvolány. Rasové předsudky, stejně jako náboženství, je proměnná, kterou je třeba do experimentu přivést $\mathrm{z}$,reálného" světa a tento přenos musí být samozřejmě explicitně součástí výzkumu. Zde se v podstatě stále nelze vyhnout dotazníkům, přinejmenším ve výběru respondentů.

\section{Subjektivita v automaticky aktivovaných postojích: nevědomé vs. automatické a nekontrolovatelné}

Metodologie implicitní sociální kognice je Gawronskim a Paynem (2010: 3) historicky umístována především do dvou výzkumných tradic - do výzkumu selektivní pozornosti a výzkumů implicitní paměti. ${ }^{30}$ Koncepty spojené původně s kognitivní psychologií získávají svůj typický charakter, když začnou být používány na řešení sociálně psychologických otázek. Ačkoliv se později začne objevovat při základním vymezení tématu i atribut nevědomého (Payne a Gawronski 2010: 3-4), existuje větev výzkumů, kde se používá především protiklad automatické a kontrolované kognice. Kontrolované procesy vyžadují pozornost, mají ohraničenou kapacitu a potřebují být volně iniciované a upravované. Automatické naopak vyžadují minimálně pozornosti, mají neohraničenou kapacitu a jsou chápány v př́imém vztahu k vědomí tím, že jsou definovány jako obtížně potlačitelné (Payne a Gawronski 2010: 2).

Na tomto rozlišování pak Fazio staví své uchopení automaticky aktivovaných postojů (Fazio, Sanbonmatsu, Powell a Kardes 1986). A to je pak dále propojeno s paradigmatem sekvenčního primingu, ${ }^{31}$ ve kterém míra automatické aktivace odpovídá síle postoje a ten je možné indikovat, aniž by na něj byl účastník př́ímo dotazován (Fazio, Jackson, Dunton a Williams 1995). Tak je dle Gawronského a Payna vyjádřena základní myšlenka sociální implicitní kognice, stejně jako její typická metodologie nepř́mého měření. To, co se v původních výzkumech implicitní paměti odráží v automatické rychlé aktivaci silně naučených asociací a v pomalejší - nebot' větší kognitivní pozornost vyžadující - aktivaci slabě naučených asociací (Schacter 1987), získá svůj typický sociální charakter v předpokládané afektivní automatické odezvě v implicitních testech rasových předsudků. Sebeprezentace je zde chápána jako další přidaný kognitivní proces, jenž by se měl projevit v celkově delším reakčním čase.

30 Implicitní pamět' (viz např́iklad Schacter 1987) je pamět' obsahující znalosti či dovednosti, které nejsou vědomě přistupné introspekci. Je to vědění, které se z principu nemůže projevit jinde než v chování.

31 Priming je psychologická technika, která předpokládá automatické změny v mentálních procesech na základě specifického vystavení určitému podnětu. Sekvenční priming (někdy též afektivní priming) odkazuje k úlohám, ve kterých podnět vyvolává automatické reakce s pozitivní nebo negativní konotací (afekty - libost/nelibost) (viz Fazio, Sanbonmatsu, Powell a Kardes 1986). 
Důležité je, že tyto problémy lze studovat, aniž by bylo nutné mluvit o vědomém a nevědomém. Ačkoliv můžeme implicitní kognitivní procesy chápat paušálně jako nedostupné vědomí a tedy „nevědomé“, je užitečnější je chápat jako nekontrolovatelné, respektive obtížně kontrolovatelné. I když př́istupnost a kontrolovatelnost jsou spojené nádoby, rozhodně nejsou zcela zaměnitelné. Pro experimentální psychologický výzkum, který mentální svět a jeho charakteristiky vyvozuje $\mathrm{z}$ behaviorálně čitelných (tj. objektivně pozorovatelných) stavů a stojí na paradigmatu měření reakčního času, je izolovaný problém vědomosti/nevědomosti umělý. Klíčovou charakteristikou automatičnosti není nevědomost, ale její mimovolní nastartování, její nevyhnutelnost (Payne a Gawronski 2010: 4). Automatické zastupuje širší rodina procesů a stavů než nevědomé. Dynamika odrážející experimentální rozpaky nad tlustou dělicí čárou mezi světem vědomí a nevědomí, respektive př́rody a kultury, i více odpovídá běžné lidské zkušenosti, kde máme přinejmenším iluzi svobodné vưle (viz Wegner 2003).

Jazyk kognitivní psychologie v podobě automatického a kontrolovaného lze přeformulovat jako otázku toho, co „děláme (můžeme dělat)“ vůči tomu „co se nám děje“ v rámci subjektivní reflexivní zkušenosti. Otázka implicitních automatických procesů je totiž zajímavá zejména s ohledem na propojení subjektu a činnosti ve smyslu kauzálního zdroje změny. ${ }^{32}$ Zkušenostní svět je pro nás tělem a těmito procesy poměrně jasně rozdělen na doménu kontroly a doménu toho, co už vnímáme za její hranicí. Osobně pokládám problém náboženské zkušenosti v jejích extrémních (konverze) i „každodenních“ podobách v kontextu toho, co lidé sami deklarují, že „se jim děje“ vůči tomu „co dělaji““ či „,mohou dělat“, za nejen zajímavý, ale pro vysvětlování náboženství i za klíčový.

\section{Adaptivní nevědomí sociální psychologie: implicitní pamět, implicitní postoj a implicitní dovednost}

Původní výzkumy implicitní paměti, v nichž byla experimentální situace ve velké míré původcem, nejen měřením, užitých konceptů a u nichž tedy můžeme metodologicky mluvit o „pravém experimentu“ “,33 mohou ještě sebevědomě deklarovat prŕmou závislost toho, co je měřeno, na tom, s čím je manipulováno. Koncepty, u nichž byla rychlost vyvolání spojena s mírou automatické aktivace, a tak se silou zapamatování, výzkumník totiž své účastníky nejdřive sám učil (Payne a Gawronski 2010: 4). Automatická aktivace v těchto výzkumech kontrastuje s kontrolovanou aktivací. Úloha totiž měřila jak explicitní vyvolání (kontrolovaná aktivace), tak implicitní př́tomnost $\mathrm{v}$ performanci, kdy měli účastníci za úkol doplňovat slova na základě jejich fragmentů. Předchozí učení se projevovalo i tam, kde účastníci nevykazovali vědomé znalosti podnětů a to bylo chápáno jako indikace implicitní paměti (Payne a Gawronski 2010: 4). Implicitní pamět’ tak bývá v tradici sociální implictní kognice obecně definovaná jako vliv minulé zkušenosti na pozdejjší výkon, za absence uvědomování si této

32 Wegnerovy (2003) psychologické výzkumy ukazující, že „zkušenost vědomé kontroly“ je oddělitelná od samotné kontrolující akce, otevírají zajímavou oblast „fenomenologie pocitu dělání“ (viz Bayne 2006).

33 Tj. lze situaci maximálně kontrolovat. 
minulé zkušenosti (Payne a Gawronski 2010: 4). Není bez zajímavosti, že jednou z indicií, která vedla $\mathrm{k}$ experimentům $\mathrm{s}$ implicitní pamětí, byli pacienti s amnézíi. Ti si nedokázali vybavit, že by se něco učili, přestože se měřitelně zlepšovali, byli-li vyučováni (Warrington a Weiskrantz 1968). Protože tato znalost není převeditelná na informaci, ale lze ji zachytit jen v jednání, bývá implicitní pamět' tradičně spojována s dovednostmi. ${ }^{34}$

S ohledem na tyto výzkumy paměti je implicitní tedy i v kognitivní psychologii vlastně $\mathrm{z}$ definice nevědomé ve smyslu nevybavované. Ale rozlišování explicitní/implicitní jako vědomé/nevědomé je i $\mathrm{v}$ tomto momentě př́liš vágní. Podstatným a skutečně indikovaným kritériem je totiž spiš předpoklad, že implicitní a explicitní pamět' jsou v mozku oddělené a jinak kódované (Rugg a kol. 1998). Fakt, že si zdraví lidé dokáží oproti lidem trpícím amnézií vybavit momenty učení, neznamená, že by jejich pamět' kvưli tomu pracovala jinak. Implicitní v sociálně psychologickém smyslu je ale především perfomanční model. Nevědomí sociální psychologie je především experimentálně testované nevědomí. ${ }^{35}$

Určitý aspekt takového nevědomí představuje koncept implicitních postojů. Greenwald a Banaji definují implicitní postoje jako ,introspekcí neidentifikované (nebo nepřesně identifikované) stopy předchozí zkušenosti, která prostředkuje příznivé a nepříznivé pocity, myšlenky a akce směrem k sociálním objektưm "36 (Greenwald a Banaji 1995: 4, kurzíva TH). Implicitně kognitivní je zde konstruováno jako kauzální prostor s relativními hranicemi dynamicky vymezenými vůči subjektivitě. Ačkoliv se objevily tendence chápat implicitní jako z principu vědomí nepř́stupné (Payne a Gawronski 2010: 4), i když Greenwald i Banaji mluvili o neidentifikovaném a ne neidentifikovatelném, pozdější výzkumy ukázaly na nečekané korelace mezi sebereflexivními výpověd’mi a implicitním měřením (Payne

34 Paměti v jejích dovednostních behaviorálních rozměrech se v rámci kognitivní religionistiky zatím nedostalo př́liš pozornosti. Hypotéza kontraintuitivních reprezentací je v empirických výzkumech zatím primárně spojena s konceptuální pamětí (Barrett a Nyhof 2001; Boyer a Ramble 2001). To se týká i dalšího proudu kognitivní religionistiky spojeného s rituální teorií Harveyho Whitehousea (2004). Whitehouse na základě Tulvingova rozlišení sémantické a epizodické paměti konstruuje koncept dvou modů náboženskosti - doktrinálního a sémantického. Tyto dva typy paměti jsou ale např́klad Squirem (1993) definovány jako tzv. explicitní pamět'. Whitehouse tedy ve své teorii implicitní pamět' v podstatě ignoruje, a tím se mimo jiné vystavuje kritice např́klad Richarda Payna, který tvrdí, že pro asijská náboženství je v rámci typického opakování ritualizovaných pohybů důležitá tzv. procedurální pamět' (Payne 2002). A ta už ve Squireově schématu patř́i $\mathrm{k}$ dovednostem $\mathrm{v}$ rámci implicitní paměti. Otevřeme-li koncept víry mimo křest’anský horizont, je jasné sepětí mentálních dispozic a rituálu a vysvitne i problém jejich oddělení v Allportově vnitřní a vnější religiozitě.

35 Jde o dost odlišné pojetí, než jaké proslavila Freudova psychoanalýza. Nevědomí zde především není ani tak jednotnou oblastí nadanou vlastní agendou, jako spíš sumou samostatných mechanismů schopných reagovat na interakci s prostředím. Často se dnes označuje termínem ,adaptivní nevědomí“. V jeho rámci se rozlišuje nevědomé ,jako 1) podmínka nebo podnět, která uvádí proces do pohybu; 2) proces samotný (tj. kroky a př́slušný algoritmus); 3) výsledek procesu; a 4) důsledky procesu“ (Hofmann a Wilson 2010: 198). Hofmann a Wilson v tomto kontextu argumentují, že výsledek automatických procesů může být za určitých okolností přistupný vědomí, a tak se na něm může podílet celá řada dalších procesů. Což samozřejmě mohou být i bohové. 
a Gawronski 2010: 7). Stejně tak byla objevena překvapivá kontextová ohebnost nepř́mých výzkumů obecně (Gawronski a Sritharan 2010). Oba typy nálezů vedou badatele k závěru, že kauzální napětí mezi automatičností a vědomím v konkrétní (nejen experimentální) situaci závisí na jedné straně na samotném kontextu a na druhé straně na př́stupnosti ${ }^{37}$ dané situace vůči volní kontrole, včetně motivace. Jinými slovy to, nakolik v dané situaci bude naše jednání kauzálně opřeno o automatičnost nebo volní jednání, závisí na souhře vnějšího (situace kolem subjektu) i vnitřního (situace v subjektu, jeho uchopení situace) kontextu. Obecně výzkumy v sociální psychologii ukazují, že to, čeho jsme si vědomi a co jsme schopni kontrolovat, je často daleko za původním očekáváním (Payne a Gawronski 2010: 8). $\mathrm{S}$ ohledem na možný strach $\mathrm{z}$ dominance vysvětlení víry na základě laboratorní redukce je pozoruhodné, že laboratorní výzkumy zde vrací kauzální mocnost zpátky $\mathrm{k}$ subjektu. V rámci duálně procesující mysli je totiž dominance jednoho systému nad druhým v zásadě věcí kontextu.

\section{Krátká historie implicitní kognice v experimentální psychologii náboženství}

Použití experimentálních metod $\mathrm{s}$ paradigmatem reakčního času př́mo ke studiu náboženské víry má poměrně krátkou historii a stále ho lze nejspíš považovat za velmi novátorské i v kontextu empirické psychologie náboženství obecně. ${ }^{38}$ Za pionýra těchto metod v experimentální psychologii náboženství lze považovat např́klad Nikolase Gibsona (2005). Ten ve své doktorské dizertaci navrhl a provedl sérii experimentů, u nichž doufal v nepřímý průzkum náboženské zkušenosti na základě specificky projevované sociální kognice vystavené předchozí náboženské socializaci. Jinými slovy zkoumal v kontrastu věŕíí a nevěrící účastníky $\mathrm{v}$ baterii speciálně vytvořených testů ve snaze najít odlišnosti $\mathrm{v}$ automatickém zpracování náboženských podnětů. Gibson se např́klad pokusil vytvořit „náboženskou“ variantu Stroopova testu ${ }^{39}$ (Stroop 1935), ve které chtěl využít efektu problematického rozpoznávání podnětu obsahujícího protikladnou informaci. Gibsonovou snahou bylo objevit na úrovni individuální kognice to, co měří i Gorsuchův dotazník, tj. efekty silné vnitřní víry. Zjistil, že evangelikální křestané vykazují významně větší interference

37 Zde by bylo vhodné zmínit termín affordability ekologické psychologie Jamese Gibsona (1977) podporující roli prostředí v době, kdy kognitivní vědě ještě kralovalo kognitivistické „,počítačové“ paradigma. Gibson předpokládal, že materiální svět sám o sobě nabízí specifickou míru interaktivnosti, jež je dána součinností prostředí a organismu a že si nelze kognici představovat oddělenou od prostředí, ve kterém se vyvíjí a ve kterém pracuje. S nadsázkou lze říci, že málo co tak vybízí k sebeprezentaci jako psychologický dotazník.

38 Poslední edice The Psychology of Religion: An Empirical Approach (Hood, Hill a Spilka 2009) věnuje implicitním metodám jen jednu stranu (487). Za komplexní, přinejmenším s ohledem na praktické shrnutí metod, může být považována nedávná studie Jonathana Jonga (2012).

39 V př́ípadě klasického Stroopova testu se jedná o podněty v podobě slov s označením barvy, prezentované ovšem v interferujícím barevném provedení (tj. například slovo „zelená“ napsané červenou barvou). 
u náboženských slov než ateisté, ${ }^{40}$ nicméně rozdíl nebyl dostatečně velký, aby mohl sloužit jako test religiozity. Jeho celkovou inspirací je nepochybně práce jeho učitele Petra Hilla, který na základě Faziova modelu automatické aktivace navrhl model zpracování postojů (attitude process model) náboženské zkušenosti (Hill 1994). Hill nemluví ještě o implicitních postojích, ale koncept postoje jako vztahu mezi objektem a jeho automatickým hodnocením čerpá ze stejné výzkumné tradice jako Greenwald a Banaji.

Postoje jako dispozice orientující, respektive motivující jednání jsou základní půdou, na které se empirická psychologie náboženství snaží rozkrýt afektivní složku náboženské víry, respektive specifické „důvěry“ nábožensky praktikujících ke klíčovým podnětům oproti nepraktikujícím. ${ }^{41} \mathrm{Na}$ druhou stranu to neznamená, že badatel musí vždy pracovat jen s náboženskou vírou $\mathrm{v}$ jejím tradičním sebevymezení, respektive jen př́mo s nábožensky věrícími. Budeme-li předpokládat, že silná přesvědčení se budou projevovat $\mathrm{v}$ rychlejších spontánních reakcích, pak můžeme stejným způsobem zkoumat také víry (přesvědčení) i sebedeklarujících se ateistů, přičemž bychom měli dojít ke stejným výsledkủm, jen u jiných podnětů.

Intuice některých křest'anů, že ateismus může být také svého druhu víra a nemusí být vždy jen produktem vědomé racionality, potvrzuje např́klad studie Cohena, Shariffa a Hilla (2008). Cohen a kolektiv zde zkoumali reakční čas kategorizace předmětů v podobě slov jako „skutečných“ nebo „imaginárních“ $s$ cílem zkoumat př́istupnost ${ }^{42}$ náboženských ${ }^{43}$ presesvědčení. Baterie obsahovala slova odkazující jak k předmětům neproblematicky imaginárním (,velikonoční zajíček"), tak k náboženským (,zázraky“), a dokonce i k předmětům možné sekulární víry (,„černé díry“). Poměrně rychlejší reakce v zařazování „náboženských“ slov do očekávatelnét4 kategorie vykazovali nakonec nejen deklarativně věŕíí účastníci, ale i deklarativně nevěřící. U žádné jiné skupiny podnětů korelace s religiozitou objevena nebyla. To ale nepřekvapí, budeme-li předpokládat, že se ohledně víry pohybujeme v Jamesově rovině praktického uvažování, pro kterou velikonoční zajíčci a černé díry nebudou př́liš relevantní objekty. Ateistický skepticismus nemusí tedy být, přinejmenším v performanci, vždy produktem vědomé racionality, kterou bychom spojili s pomalým, reflektivním „systémem 2“.

40 Stroopův test má svoji emocionální variantu. U osob s diagnostikovanou úzkostlivostí byl objeven „Stroopův efekt“ (tj. zpomalená reakce rozpoznání barvy) u slov s negativním emocionálním obsahem (Williams, Mathews a MacLeod 1996). Gibsonovo racionále spočívalo v předpokladu, že díky automatické aktivaci náboženského významu podnětů bude úloha rozpoznání barvy pro silně věříí křest’any obtížnější.

41 V křest’anském kontextu můžeme říci věřícím a nevěřícím, nicméně jsme zde vždy v podobných problémech jako třeba Allport. Tradicí psychologických šetření je vždy opatrné odkazování k sebedeklarativním zařazení (zde může Gorsuchův dotazník stále plnit svou funkci) a teprve př́padná korelace vnitřní religiozity s implicitními měřeními by mohla zmírnit pochybnosti vůči konstruktu. To byla i původní intuice Petra Hilla ohledně nepřímých měření (Hill 1994: 304, 310).

42 Jak podotýká Jong (2012: 71), výsledky studie lze interpretovat nejen jako větší př́stupnost náboženských přesvědčení, ale i jako míru implicitní asociace mezi podněty a atributy „skutečný“ a ,imaginární“.

43 Ve smyslu k náboženským obsahům se vztahující, nikoliv nějak esenciálně náboženské.

44 Ateisté do kategorie imaginární, věřící do kategorie skutečné. 
Tomáš Hampejs: Náboženství v laboratoři sociální implicitní kognice...

\section{Víra a světonázorová přesvědčení: ateismus jako „náboženská" víra?}

Tento předpoklad dále rozvádí studie Jonathana Jonga (Jong, Halberstadt a Bluemke 2012) zabývající se efektem představ smrtelnosti na světonázorová přesvědčení spjatá s náboženskými obsahy - podle mého názoru jde o jeden z nejzajímavějších experimentů sledujících souhru obou úrovní kognice $\mathrm{v}$ jednom designu. Studie zkoumala sílu světonázoru ateistů a věřících křest'anů s vlivem nezávislé proměné v podobě primovaného pocitu vlastní smrtelnosti. Výsledky explicitních dotazníků odrážejících „explicitní víru“ indikovaly po vystavení účinku nezávislé proměnné zesílení vlastního přesvědčení ${ }^{45}$ u obou skupin. ${ }^{46}$ Nicméně výsledky měření implicitních postojů ukázaly, že jen věřící účastníci jsou si jistější v rozpoznávání náboženských konceptů jako reálných, kdežto ateistický skepticismus $\mathrm{k}$ jejich nerealitě ztrácel na síle. Autoři studie výsledek explicitní víry interpretují jako performanční okamžik obhajoby osobního světonázoru. Budeme-li ateistickou jistotu v rozpoznávání náboženských podnětů klasifikovat jako postoj mající explicitní a implicitní složku a implicitní budeme chápat jako důvěru, jež nám umožňuje srovnávat přesvědčení naprŕíc náboženskou i nenáboženskou vírou, pak jako nesmírně zásadní vysvitne role situace.

Postoj jako zdroj jednání a zároveň jako důsledek specifické socializace je ohebný jak ve své implicitní, tak explicitní rovině. Specifická implicitní dovednost jako souhrn implicitních postojů, jak bychom mohli víru chápat (ve smyslu automatické orientace ovlivňující chování a jednání v prostředí), je tedy použitelná (a užitečná) jen v určitém situačním kontextu. Jak už lze vyvodit z Gibsonovy náboženské verze Stroopova testu, implicitní část víry může $\mathrm{v}$ rámci orientace $\mathrm{v}$ prostředí stejně tak pomáhat jako překážet. Evoluční výhoda kognice, která disponuje dvěma systémy, jež se mohou vzájemně korigovat, je nasnadě. Pro zkoumání náboženské víry je v tomto ohledu důležité, že se vlastně nijak neliší od jiných přesvědčení s afektivním implicitním rozměrem. A že tak např́iklad můžeme ateismus, respektive „přesvědčenou“ i vlažnou nevíru v kontraintuitivní reprezentace obecně interpretovat nikoliv jen jako vědomé reflektivní racionální přesvědčení o realitě, ale $\mathrm{i}$ jako nepř́itomnost implicitních postojů/dovedností, jež by umožňovaly s náboženskými koncepty intuitivně pracovat v Jamesově rovině ,praktického uvažováni'“ ${ }^{47}$ Naopak budeme-li víru chápat zejména

45 Tedy u křest’anů, že křest’anský Bůh a s ním spjaté koncepty mají reálnou existenci; u ateistů, že nemají.

46 Autoři studie rozdělili obě skupiny na dvě části, jednu vystavili situaci vyvolaného pocitu smrtelnosti, jednu ponechali jako kontrolní.

47 Budeme-li se pohybovat v Sperberově modelu kulturního přenosu (Sperber 1996) a jeho teorie relevance (Wilson a Sperber 2004), kde hraje klíčovou roli inferenční model komunikace, tj. komunikace nikoliv jako přenos sdělení, ale přenos stop/evidencí, pomocí kterých je význam vždy znovu vytvářen (inferován) podle možností kognice a předchozí zkušenosti, pak pro ateisty nejsou náboženské koncepty intuitivně relevantní. Tj. automatická část kognice k nim neposkytuje žádné relevantní inference. Bylo by možné dokonce spekulovat, že jsou vlastně negativně relevantní, protože pokud jsou v sociálním prostředí jako relevantní označovány, tak se bez přirozené osobní automatické relevance $\mathrm{k}$ sociálně interagovaným objektům dostávají do situace kognitivní disonance. Klíčovou otázkou samozřejmě je, nakolik je možné se této intuitivní relevanci, respektive víre jako implicitní dovednosti naučit. Jak vlastně vzniká a je předávána v rámci kulturního přenosu? Pozoruhodný model v diskusi s Danem Sperberem nabízí třeba Tim Ingold (2001), když v duchu 
$\mathrm{v}$ rovině implicitní afektivní orientace ([ne]důvěry), pak nejspiše lze určitý ateismus považovat za „víru“. ${ }^{48}$

\section{Situační ohebnost implicitních postojů}

Nicméně můžeme-li podle Jonga očekávat ohebnost ateistického světonázoru dle situačních faktorů, mělo by tomu být i u postoje náboženského. Výsledky experimentální studie Gervaise a Norenzayana (2012a) přináší podporu přesvědčení, jež může být intuitivně vlastní všem psychologizujícím teoretikům sekularizace, tj. že náboženská víra je negativně podmíněna analytickým myšlením. Tato studie nepouživá paradigma reakčního času a měří religiozitu jen pomocí sebereflektivních škál, nicméně pracuje s primingem (nepř́mou tematizací určitého fenoménu ve snaze o automatickou aktivaci s ním souvisejících konceptů a procesů) a ukazuje na zajímavou situační součinnost obou systémů kognice. V jednom z pěti experimentů, které byly součástí studie, měli účastníci za úkol ohodnotit vlastní víru v Boha na škále 0 až 100 po tom, co byli vystaveni vizuálnímu primingu v podobě fotografie antické realistické sochy přemýšlejícího muže nebo diskobola. Tj. analytické myšlení bylo v tomto ohledu jen asociačně „,vyvoláváno“. Skupina vystavena soše „Myslitele“ vykázala významně menší výsledky sebehodnotící víry než druhá skupina, ačkoliv přinejmenším explicitní religiozita byla $\mathrm{v}$ obou skupinách stejná. Tato studie vykazuje tvưrčí použití primingu a jasně poukazuje na otázku, jak trvalého charakteru jsou vlastně naměřené postoje. Bez zopakování experimentu za použití nepř́mých metod měření nemůžeme přesně říci, jaká část víry je vlastně ,analytickým myšleni““ zasažena, ale v každém př́ípadě je zřejmé, že víra jako měřený postoj je v mnohém otázkou konkrétní performance. ${ }^{49}$

Opačně orientovaný experiment, ve kterém je pro změnu vyvolávána náboženská víra, či respektive jeden z jejích možných efektů, provedli Norenzayan se Shariffem (Shariff a Norenzayan 2007, respektive Gervais a Norenzayan 2012b). Stejně jako v předchozím experimentu byli jeho účastníci vystaveni primingu; tentokrát aktivace „konceptu Boha“ způsobila zvýšenou míru tzv. prosociálního chování, jež bylo indikováno metodologií behaviorální ekonomie $\mathrm{v}$ podobě kontrolované hry $\mathrm{s}$ měřenou štědrostí. ${ }^{50}$ Zajímavé je, že př́padná sebedeklarativní náboženskost nehrála ve výsledku žádnou roli a pouhá

implicitního učení a s odkazem na psychologické teorie pevného sepětí kognice a prostředí (viz Ingold 2000) chápe kulturu jako „vzdělávání pozornosti“.

48 Ten, který bude vykazovat implicitní orientaci k náboženským obsahům. Nejde o to, dělat $\mathrm{z}$ ateistů věřící osoby $\mathrm{v}$ náboženském slova smyslu, ale o to ukázat, že pokud budeme náboženskou víru rozpoznávat podle náboženských obsahů, pak určité kognitivní složky víry v podobě implicitních postojů můžeme nalézt i u těch, kteří sami sebe deklarují jako „nevěříci““.

49 Symbolika užitá $\mathrm{v}$ rámci náboženských rituálů získává $\mathrm{s}$ ohledem na jev primingu zajímavé rozměry. Přrirozeně se zde vnucuje otázka universality takových aktivujících podnětů. Fungoval by priming podnětem „Myslitele“ transkulturně? Možné důsledky studie autoři rozvádějí v textu s název „Origins of Religious Disbelief“ (Původ náboženské nevíry) postulací čtyř typů ateismu (Norenzayan a Gervais 2013).

50 Jde o hru „diktátor“: účastníci rozdělovali více finančních zdrojů anonymním cizincům, když byli před tím vystaveni primingu konceptů Boha, než když byl priming neutrální či úplně chyběl. 
aktivace náboženského konceptu způsobila zvýšení prosociality alias důvěry v smysluplnost kooperace bez ohledu na explicitní náboženskou př́slušnost. Autoři studie jev vysvětlují $\mathrm{v}$ rámci teorie nadlidských činitelů jako vševidoucích strážců jednání, vytvářejících implicitní pocit všudypřítomné kontroly, jenž má svůj efekt ve snížení motivace pro případné nekooperativního jednání. ${ }^{51}$

\section{Víra jako dynamická dispozice: kognitivní modely postojů}

Víra jako osobní dispozice však v zásadě předpokládá jistou trvalost postojů, které ji tvoří. Máme-li si ji představit jako implicitní orientační dovednost, nebude možné ji chápat staticky jako jednou a pro vždy naučenou schopnost podobnou jízdě na kole. Budeme-li bohy chápat jako sociální objekty a budeme-li předpokládat, že míra komplexity vztahu $\mathrm{k}$ nim $\mathrm{v}$ zásadě může nabývat podobných rozměrů jako míra komplexity sociálních vztahů obecně, není ohebnost přinejmenším implicitních rozměrů víry s ohledem na evoluční kontext sociality nijak překvapivá. Důvěra je nejen v lidských skupinách dynamickou komoditou a bylo by poměrně evolučně nevýhodné, kdyby tato orientující dovednost nemohla podléhat změnám a úpravám podle momentální situace $\mathrm{v}$ prostředí, ve kterém se má jedinec orientovat. Náboženská víra ve svých implicitních automatických rozměrech tedy nemůže být z principu mechanismů, na kterých stojí, statickou záležitostí. Klíčovým pro další výzkum těchto prvků náboženství je tedy disponovat metodologií, která je schopna postihnout tento fenomén vůči jemu relevantním faktorům, respektive správně uchopit jednou silnou a jindy slabou míru „náboženského přesvědčení“, a zároveň rozumět příčinám jeho proměn i stabilizace. To ale znamená zejména disponovat specifickými modely takového přsesvědčení, tedy vírou modelovanou jako mentální reprezentace $\mathrm{v}$ podobě propozičního předsvědčení, ale $\mathrm{i} v$ podobě afektivního vztahu.

Pokud víru můžeme uchopit jako implicitní postoj (původně Greenwald a Banaji 1995), co je to implictní postoj? Je to vztah mezi různými mentálními reprezentacemi, nebo př́mo implicitní mentální reprezentace (Carlston 2010)? Sociální implicitní kognice zná oba modely mentální reprezentace - informační diskrétní i konekcionistický. Když však Carlston tvrdí, že „mentální reprezentace jsou základní bloky lidského systému paměti [...], ale bohužel je celá řada rozdílných modelů paměti“ (Carlston 2010: 39), pak je zřejmé, že jsou to prostě různé modely. Implicitní a explicitní si lze představit bud' jako rozdílné typy mentálních reprezentací, ${ }^{22}$ anebo i jako rozdílné stavy jednoho typu reprezentací (Carlston 2010: 39). A dokud nebudeme moci pracovat s mentálními reprezentacemi př́mo na fyzické úrovni mozku, modely budou odpovídat především způsobu uchopení performancí, podle kterých

51 Více o náboženství jako jevu koordinujícím prosociální chování a podílejícím se na rozvoji organizovaných společností např́klad Sosis a Alcorta (2003). O výlučném vztahu náboženství a prosociality, či morálního rozhodování však nejspíše nemůžeme mluvit ani v primingových studiích. Podobného efektu jako Norenzayan a Shariff docílili Ma-Kelams a Blascovich (2013) s primingem konceptu ,vědy“.

52 Zde se nachází např́iklad Tulvingův model epizodické a sémantické paměti (1985, in Carlston 2010), na němž je založena Whitehousova rituální teorie. 
budeme mentální reprezentace indikovat. Budoucností výzkumu víry v rámci sociální implicitní kognice je její provázanost se sociální neurovědou (Ito 2010). Z hlediska diskuse uvnitř kognitivní vědy o procesech pro kognici relevantních je důležité, že afektivní složka kognice už dávno není vnímána jako oddělený samostatný proces, jako tomu bylo v klasickém kognitivismu. Myšlení, emoce a chování jsou v současné době zkoumány a modelovány spojitě (viz např́klad Damasio 1994 nebo Clark 2008).

Pro sociální implicitní kognici je typické uchopení mentálních reprezentací jako mezi sebou provázaných a rozdílně př́stupných (Carlston a Smith 1996). To odkazuje na jedné straně např́ílad $\mathrm{k}$ implicitnímu asociačnímu testu, který měří provázanost asociací na úrovni implicitní paměti (Lane, Banaji, Nosek a Greenwald 2007), ale také například k už zmíněným výzkumům „přístupnosti náboženských konceptư“ (Cohen, Shariff a Hill 2008). Struktura náboženské víry se totiž pro psychologii dobře otevírá až v momentě, když dokáže rozlišit silná a slabá přesvědčení nad rámec reflektivní výpovědi a může se, například v př́ipadě korelací náboženství a zdraví (Hill a Pargament 2003), vyhnout komplikacím Allportovy (Allport a Ross 1967) vnitřní a vnější religiozity.

\section{Přiklad metody: implicitní asociační test}

Experimenty s primingem lze obtížně standardizovat a budeme-li hledat řešení, které by mohlo důstojně sekundovat či dokonce nahradit dotazníky sebe-deklarativní religiozity adresující afektivní složky vztahu, musíme se vrátit zpátky k úlohám s reakčním časem. Slibnou se ukazuje už relativně prozkoumaná aplikace dual-task paradigmatu ${ }^{53} \mathrm{v}$ sociální implicitní kognici (jejímž př́kladem je např́ílad i Stroopův test) v podobě tzv. implicitního asociačního testu - IAT..$^{54}$ Ten si s ohledem na představení typických vlastností úloh s reakčním časem a laboratoře sociální implicitní kognice zaslouží být pojednán podrobněji.

Tradičníi ${ }^{55}$ IAT je metoda nepř́mého měření konstruktu používající reakční čas jako odraz asociačních procesů. Konstrukt měření je možné chápat jako implicitní postoj ${ }^{56}$ vyjádřitelný silou asociačního spojení mezi kategoriemi, jejichž vzájemný vztah tento postoj reprezentuje. IAT sám je pak počítačově administrovaný test skládající se ze série pěti, respektive sedmi bloků kategorizačních úloh, ve kterých účastníci zařazují v centrální části obrazovky se objevující stimuly (v obrazové či slovní podobě) do jejich prríslušných polárně mapovaných

53 Typ psychologické experimentální úlohy, ve které je participant vystaven nutnosti zabývat se dvěma úlohami najednou. $Z$ výsledku, respektive ze specifické interference obou úloh, jsou vyvozovány závěry o sdílených informace zpracovávajících zdrojích.

54 O IAT viz Greenwald a kol. (1998) nebo Lane, Banaji, Nosek a Greenwald (2007); praktické shrnutí Teige-Mocigemba, Klauer a Sherman (2010); v kontextu zkoumání náboženství viz Jong (2012).

55 Metoda si za patnáct let své existence získala značnou pozornost a existuje v celé řadě variant.

56 Je však důležité dodat, že tyto postoje mohou odpovídat jak postojům ve smyslu vlastností, tak momentálním stavům (Teige-Mocigemba, Klauer a Sherman 2010: 120). Viz. „ohebnost“ IAT (Han, Czellar, Olson a Fazio 2010). Stejně tak je nejde jednoduše vztahovat jen k individuálním postojům, protože osobní implicitní postoje lze interpretovat i jako implicitní normativní evaluace (Yoshida, Peach, Zanna a Spencer 2012), tj. jako neosobní vědění získané socializací. 
kategorií (zobrazených v levém či pravém rohu) pomocí dvou kláves. Základním principem je zařazení stimulu (stiskem př́ślušné klávesy) do levé nebo pravé části obrazovky podle toho, kde se právě nachází mateřská kategorie př́slušného stimulu. Tradiční IAT má čtyři kategorie dvou typů, cílového (tj. např́klad Obama a Bush; květiny a hmyz nebo Bůh a Ďábel) ${ }^{57}$ a atribučního (tj. např́iklad pozitivní/negativní). Každá kategorie se skládá ze skupiny konkrétních stimulů, které $\mathrm{v}$ testu kategorii reprezentují (zpravidla jsou to slova nebo obrázky jasně patřící do př́islušné kategorie). Samotná kategorizace stimulu do kategorie by měla být neproblematická, zpomalující interferenční efekt by měl nastat v kontrastu síly asociačního vztahu mezi cílovou a atribuční kategorií. Jedno vysvětlení principu měření založeného na interferenci zpracovávání dvou odlišných informací v jednom okamžiku spočívá v předpokladu, že kategorizace je snadnější, pokud asociované koncepty sdílejí stejnou klávesu, než když vyžadují rozdílnou (De Houwer 2003), a to ovlivňuje reakční čas. Ze sedmi bloků standardního IAT jsou pro asociační měření důležité jen dva (respektive čtyři podle metody kalkulace výsledku) z nich a ostatní slouží jako prostor pro nacvičení rozlišování. Dva klíčové bloky představují „kompatibilni““ a „nekompatibilni“ kategorizační situaci a z porovnání reakčních časů mezi těmito bloky se odečítá tzv. IAT efekt, tj. výsledek testu.

Jedno z možných vyhodnocení IAT je tzv. D, ${ }^{58}$ což je číselný výsledek metod inferenční statistiky nabývajících hodnot mezi -2 až 2 . Reprezentuje sílu asociace mezi oběma cílovými kategoriemi a atributem. Např́klad $\mathrm{D}=-0,1$ by v př́padě cílového konceptu Bůh a atributu Já znamenalo slabé implicitní asociační spojení mezi Ďáblem a konceptem Já, respektive Bohem a Nejá, kdežto $\mathrm{D}=0,5$ by znamenalo stredně silné ${ }^{59}$ asociační spojení mezi Bohem a Já. Jak je zřejmé, výsledek IATu je v základu relativní. Dvě atribuční kategorie by tedy měly reprezentovat jednu škálu.

Jakkoliv v základu je metoda poměrně jednoduše formulovaná, její implementace mohou být nakonec různé. Protože kognitivní procesy zakládající IAT nejsou stále jasné (Jong 2012; Olson a Fazio 2003), nelze mimo jiné obecně formulovat model zahrnující všechna možná př́ípadná zkreslení (Teige-Mocigemba a kol. 2010: 124) a metodu úplně standardizovat. Navíc je problém, že u většiny, ne-li u všech implicitních měření, stále ještě dostatečně nerozumíme komplexitě spojení mezi měřeným konstruktem a pozorovatelným chováním (De Houwer, Teige-Mocigemba, Spruyt a Moors 2009; Moors, Spruyt a De Houwer 2010).

Pro každou IAT studii je zásadní, aby kategorizace stimulů probíhala skutečně podle asociačního členství $\mathrm{v}$ př́slušné kategorii. Jednou $\mathrm{z}$ neblahých strategií řešení úlohy je totiž tzv. „rekódování“ (Teige-Mocigemba a kol. 2010: 127), ve kterém dochází k třídění na základě podružných vlastností stimulů (např́ílad délky slov). Snahou je tedy zabránit vytvoření jiného možného kritéria pečlivou př́pravou stimulů. Důležitý je ale samozřejmě

57 Zajímavou implementaci IAT předkládá studie o vertikalitě implicitních představ božskosti, podle které je koncept pozitivní božskosti (Bůh) spojen s vysokou vertikalitou a koncept negativní s nízkou (Meier, Hauser, Robinson, Friesen a Schjeldahl 2007).

58 D je statickým výsledkem porovnání reakčních časů kompatibilních a nekompatibilních bloků.

59 D je zvykem klasifikovat ve třech kategoriích - slabé $(\mathrm{D}>0,15)$, střední $(\mathrm{D}>0,35)$ a silné asociace (D $>0,65)$ podle psychologických konvencí velikosti účinku. Viz text „Race attitude“, $<$ https:// implicit.harvard.edu/implicit/demo/background/raceinfo.html>. 
i správně zvolený popisek cílových kategorií. IAT vytváří specifický situační kontext a výsledný měřený konstrukt odráži kombinaci kategorií a stimulů. Jinými slovy volbou stimulů je možné kategorie určitým způsobem konotovat (Bluemke a Friese 2006).

Dobrým př́kladem náboženského IATu, který by mohl měřit náboženskou víru v jejích implicitních rozměrech, je tzv. varianta IATu s jednou cílovou kategorií (ST-IAT, Karpinski a Steinman 2006) v implementaci Shariffa, Cohena a Norenzayana (2008). Autoři ve studii s názvem „The Devil's Advocate: Secular Arguments Diminish both Implicit and Explicit Religious Belief (Ďáblův advokát: Sekulární argumentace zeslabuje implicitní i explicitní náboženskou víru)“ zpracovávají podobný problém jako o pár let později Gervais a Norenzayan, tj. kontakt sekulárních stimulů a náboženské víry. Podnětem $v$ jejich př́padě je výňatek z Dawkinsovy knihy God's Delusion (2006), obhajující evoluční př́stup ke vzniku a vývoji života a pranýřování iracionálnosti opačných přesvědčení spjatých s náboženstvím. Závěr studie vyznívá jednoznačně ve prospěch názoru, že náboženská víra má daleko do stabilní jednorozměrné dispozice a že propagandistická rétorika je pro cílenou situační změnu postojů skutečně funkční, protože náboženskost po stimulaci Dawkinsovým diskurzem na všech úrovních klesla. Kdyby byla náboženskost měřena jen explicitními metodami, bylo by možné namítnout, že výsledky experimentu signalizují sebeprezentační zkreslení - tedy snahu účastníků stylizovat se do explicitní atmosféry experimentální situace konotované textem profesora Dawkinse; nicméně konvergence výsledku na obou úrovních kognice dovoluje mluvit o hlubším efektu. ${ }^{60}$

\section{Redukce víry v kognitivní laboratoři: spojené nádoby implicitního a explictního $\checkmark$ jednání}

Trvalost a stálost implicitních postojů jako osobnostních rysů nabytých předchozí zkušeností se tady přinejmenším komplikují (např́klad Gawronski, LeBel a Peters 2007). Vztah a vzájemná ovlivnitelnost mezi oběma úrovněmi kognice situaci neusnadňuje jak z hlediska měření, tak s ohledem na vlastnosti implicitních dispozic jako takových. Je třeba mít na paměti, že dualita vnucená kontextem metody i teorie však nemusí být na úrovni samotné psychiky odpovídající. Častá korelace mezi implicitními a explicitními měřeními jednoho konstruktu napovídá, že odkazují k rozdílným, ale spojeným mentálním dispozicím (Nosek 2007). Obecně se zdá, že implicitní měření budou správně predikovat chování tam, kde lze očekávat sníženou možnost kontroly pomocí exekutivních procesů (Friese, Hofmann a Schmitt 2009). To nahrává významu implicitních složek náboženství v situacích, kde lze očekávat limity lidské moci v jejích objektivních i subjektivních podobách. ${ }^{61}$

60 Jestliže explicitní sekulární argumenty zjevně zasahují i akfektivní složky naší kognice, chybí mi v experimentech doplňková studie pocitů účastníků ohledně jejich prožívání takového efektu, tj. to, nakolik jsou si ho př́ípadně vědomi a zda-li z něho mají pocit nepohodlí. Případná kognitivní disonance, která v takové situaci nastává, dovoluje lépe pochopit automatické obranné mechanismy, které lze anekdoticky předpokládat při konfrontace silně věřících a „silně nevěřících“.

61 Situace s falešným detektorem lži (Sigall a Page 1971) ukazuje, že stačí, když věříme, že nemáme možnost situaci ovlivnit, a dáváme větší prostor automatickému spontánnímu chování. 
Situační ohebnost implicitních postojů pak vyvolává, s ohledem na koncept adaptivního nevědomí, poněkud jiný obraz odpadního skladiště mysli, než jak ho kreslí klasická psychoanalýza, tj. především traumatizovaného předchozí životní zkušeností. Kontextově pracující intuitivní kognice se tak jeví být aktivní součástí snahy organismu neustále se přizpůsobovat prostředí a dodávat ke každé situaci relevantní informace a behaviorální incentivy, např́klad $\mathrm{v}$ podobě relevantních automatických evaluativních soudů $\mathrm{v}$ rámci rozhodování (Bodenhausen a Todd 2010). Implicitní postoje jsou však nejen dispozice k automatickým soudům, jako podstatný vidím jejich z hodnocení situace vyplývající akční rádius zakládající možné jednání. Ve smyslu pragmatismu Williama Jamese, „psychologicky skutečné“ je v rovině „praktického uvažování“ prostě skutečné. I když to samozřejmě neznamená, že je to zároveň nutně (automaticky) funkční, výhodné či univerzální.

Domnívám se, že obraz víry pocházející z laboratoře sociální psychologie s jejími operacionalizovanými konstrukty implicitní kognice a dekontextualizovaností nejeví známky ničivého neproduktivního protikladu $\mathrm{k}$ hermeneutické bohatosti světa subjektivní zkušenosti. Laboratorní výzkum lidského jednání může vést místo $\mathrm{k}$ „nežádoucímu“ zjednodušování osob na věci, respektive mechanismy, i k smysluplné komplexitě vztahů, jež nejsou jinak tolik patrné. Především tím, že studuje samotnou hranici mezi subjektivitou a objektivitou, se symetrickým ohledem na obě úrovně.

\section{Závěr}

Z hlediska akademického studia náboženství a integrace paradigmatu sociální implicitní kognice do repertoáru metod např́íklad religionistiky je na místě otázka, nakolik můžeme o viře v laboratoři mluvit jako o transkulturním fenoménu. Jak je zřejmé ze samotného psychologického pojetí náboženskosti jako víry (Allportova náboženská orientace) a samožrejmě ze skutečnosti, že typický zkoumaný vzorek populace (vysokoškolští studenti psychologie) se nese plně ve značce WEIRD (White European Industrial Rich Democratic) (viz Henrich, Heine a Norenzayan 2010), sociální implicitní psychologie zkoumající náboženství nemůže být zdaleka samostatnou disciplínou. ${ }^{62}$ Nutně potřebuje kognitivní vědu o náboženství s její univerzalistickou snahou rozumět nábožensky relevantním procesům skutečně nezávisle na kultuře, a stejně tak se musí pokusit vyjít se svými metodami mimo laboratoře evropských univerzit, za „přirozeně se dějícím“ náboženstvím. Počítačově realizovaná laboratoř reakčního času působí značně přenositelně ${ }^{63}$ a koncept automatického zařazování stimulů v rámci kategorií se nezdá být závislý na kultuře zkoumané populace. Co v důsledku laboratorní výsledky sociální psychologie potvrzují především, je důležitost kontextu. Nepř́mé metody sociální implicitní kognice nejsou žádná via regia do nevědomí jako zdroje lidského chování. Tím experimentální pole sociální psychologie stojí slibně na půl cesty mezi kognitivní vědou o náboženství $\mathrm{s}$ její přirozenou snahou náboženství dekontextualizovat, $\mathrm{s}$ ohledem

62 V kontextu WEIRD a bez antropologické zkušenosti kognitivní vědy o náboženství je v mnohém spíše jakousi experimentální etnometodologií „post-křest’anské“ euroamerické civilizace.

63 Alternativní cestou může být oživení papírových metod (Sekaquqaptewa, Vargas a Von Hippel 2010). 
na univerzální evolučně vyvinuté kapacity, a klasickým historickým a etnografickým výzkumem náboženství s jeho přirozenou afinitou ke kontextu.

Co může říci sociální implicitní kognice ke Kierkegaardově Abrahámovi? Především to, že náboženskou víru je třeba studovat $v$ komplexitě vztahů, ve kterých se projevuje, a je třeba ji studovat komplementárně mnoha metodami, tedy že ji v zásadě nelze oddělit od náboženské praxe (performance) či s náboženstvím ztotožnit. ${ }^{64}$ Důvodem $\mathrm{k}$ tomu může být mimo jiné zřejmé kognitivní propojení všech tří složek víry traktovaných filosofií náboženství. Experimentální výzkum je nutným doplněním doposud opomíjeného behaviorálního rozměru náboženské víry, aspektu, jenž specificky odráží víru ve všech třech ohledech konání, myšlení i cítění, a ukazuje tak jejich propojenost. Tento pohled nakonec podporuje nejen deesencializaci víry jako sui generis dispozice, ale umožňuje vhled do pro ní podstatných prvků na hranici a za hranicí osobní vědomé zkušenosti, na kterou jsou odkázány tradiční metody neexperimentálních historických a sociálních věd. Náboženskou víru samožrejmě osvobodit od jejího komplikovaného vztahu $\mathrm{k}$ subjektivitě, respektive $\mathrm{k}$ oběma úrovním lidské kognice, nelze. Stále zde má smysl mluvit o chování a jednání, nebo alespoň o dvou úrovních chování, jak v rámci přirozeného světa, tak v laboratorní performanci. Výzkumy náboženství v laboratoři by tedy ideálně měly ruku $\mathrm{v}$ ruce kráčet se standardními neexperimentálními historickými a antropologickými metodami. Jen skrze integrované modely lidské zkušenosti vedoucí např́ič př́rodními a humanitními vědami můžeme uchopit jevy emicky spjaté s konceptem „náboženské víry“ jako určitý obecný rys lidského chování a mluvit o jeho vědeckém vysvětlení. Studium víry uchopené jako implicitní dovednost poskytující (ne)praktickou afektivní (dis)orientaci v rámci určitých situací každodenního života je ale samozřejmě teprve na svém počátku. Jakou roli hrají v těchto dovednostech nadlidští činitelé, ${ }^{65}$ respektive jakou roli hrají implicitní dovednosti s nimi spjaté v komplikované síti činností a významů, jež označujeme za náboženství, to je třeba teprve ukázat. Modely a metody sociální implicitní kognice zde poskytují nejen nástroje, jimiž je možné určité složky náboženské víry měřit, ale především realizují podstatný vhled do povahy této víry.

\section{Bibliografie}

ALLPORT, Gordon a J. Michael ROSS. Personal religious orientation and prejudice. Journal of personality and social psychology, 1967, roč. 5, č. 4, s. 432-443. ISSN 0022-3514.

ATRAN, Scott. In Gods We Trust: The Evolutionary Landscape of Religion. 1. vyd. New York: Oxford University Press, 2002. ISBN 0195178033.

BARRETT, Justin L. Exploring the natural foundations of religion. Trends in Cognitive Sciences, 2000, roč. 4, č. 1, s. 29-34. ISSN 1364-6613.

64 K tomu může mít tendence na jedné straně protestantské křest'anství a psychologie v jeho kontextu obecně, na druhé straně i „,noví ateisté“, jako je Richard Dawkins, pro kterého náboženství konotuje jednodimenzionální víru v nadlidské bytosti a demonstruje ignoranci empirické evidence a racionálního myšlení.

65 Kteří hrají klíčovou roli v minimalistické definici náboženství kognitivní religionistiky jako chování a myšlení spjatého s nadlidskými činiteli. 
BARRETT, Justin L. Why Santa Claus is Not a God. Journal of Cognition \& Culture, 2008, roč. 8, č. 1/2, S. 149-161. ISSN 15677095.

BARRETT, Justin L. a Frank C. KEIL. Conceptualizing a nonnatural entity: Anthropomorphism in God concepts. Cognitive psychology, 1996, roč. 31, č. 3, s. 219-247. ISSN 0010-0285.

BARRETT, Justin L. a Melanie A. NYHOF. Spreading non-natural concepts: The role of intuitive conceptual structures in memory and transmission of cultural materials. Journal of Cognition and Culture, 2001, roč. 1, č. 1, s. 69-100. ISSN 1568-5373.

BAYNE, Tim. Phenomenology and the feeling of doing: Wegner on the conscious will. In POCKETT, Susan, William P. BANKS a Shaun GALLAGHER (eds.). Does consciousness cause behavior. 1. vyd. Cambridge, MA: The MIT Press, 2006, s. 169-186. ISBN 9780262281690.

BELL, Catherine M. Ritual theory, ritual practice. 1. vyd. New York: Oxford University Press, 1992. ISBN 0195076133.

BISHOP, John. Faith [online]. Fall 2010 [cit. 30.6.2013]. Dostupné z: <http://plato.stanford.edu/archives/fall2010/entries/faith/>

BODENHAUSEN, Galen V. a Andrew W. TODD. Automatic Aspects of Judgment and Decision Making. In GAWRONSKI, Betram, a Keith B. PAYNE (eds.). Handbook of implicit social cognition: measurement, theory, and applications. 1. vyd. New York: The Guilford Press, 2010, s. 278-294. ISBN 9781606236734.

BOYER, Pascal. The Naturalness of Religious Ideas: A Cognitive Theory of Religion. 1. vyd. Berkeley, CA: University of California Press, 1994. ISBN 0520075595.

BOYER, Pascal. Religion explained: The evolutionary origins of religious thought. 1. vyd. New York: Basic Books (AZ), 2001. ISBN 9780465006953.

BOYER, Pascal. Religious thought and behaviour as by-products of brain function. Trends in cognitive sciences, 2003, roč. 7, č. 3, s. 119-124. ISSN 1879-307X.

BOYER, Pascal. A reductionistic model of distinct modes of religious transmission. In WHITEHOUSE, Harvey a Robert N. McCAULEY (eds.). Mind and religion: Psychological and cognitive foundations of religiosity. 1. vyd. Oxford: AltaMira Press, 2005, s. 3-29. ISBN 9780759106185.

BOYER, Pascal a Charles RAMBLE. Cognitive templates for religious concepts: Cross-cultural evidence for recall of counter-intuitive representations. Cognitive Science, 2001, roč. 25, č. 4, s. 535-564. ISSN 1551-6709.

CARLSTON, Don E. Models of implicit and explicit mental representation. In GAWRONSKI, Bertram a Keith B. PAYNE (eds.). Handbook of implicit social cognition: measurement, theory, and applications. 1. vyd. New York: The Guilford Press, 2010, s. 38-61. ISBN 9781606236734.

CARLSTON, Don E. a Eliot R. SMITH. Principles of mental representation. In HIGGINS, E. Tory a Arie W. KRUGLANSKI (eds.). Social psychology: Handbook of basic principles. 1. vyd. New York: The Guilford Press, 1996, s. 184-210. ISBN 9781572301009.

CLARK, Andy. Supersizing the Mind: Embodiment, Action, and Cognitive Extension. 1. vyd. New York: Oxford University Press, 2008. ISBN 0195333217.

COHEN, Adam B. et al. Furthering the Evolution of Discussion on Religion: Multi-Method Study, Universality, and Cultural Variation. In BULBULIA, Joseph et al. (eds.). Evolution of Religion: Studies, Theories, and Critiquies. 1. vyd. Santa Margharita, CA: Collins Foundation Press, 2008, s. 333-339. ISBN 9780978844110.

COHEN, Adam B., Azim F. SHARIFF a Peter C. HILL. The accessibility of religious beliefs. Journal of Research in Personality, 2008, roč. 42, č. 6, s. 1408-1417. ISSN 0092-6566.

COOLICAN, Hugh. Research methods and statistics in psychology. 5. vyd. London: Hodder Education, 2009. ISBN 9780203769669.

DAMASIO, Antonio. Descartes' error. 1. vyd. New York: Putnam, 1994. ISBN 9780399138942. 
DAWKINS, Richard. The God Delusion. 1. vyd. Boston, MA: Houghton Mifflin Harcourt, 2006. ISBN 9780547348667.

DOVIDIO, John F., Kerry KAWAKAMI a Samuel L. GAERTNER. Implicit and explicit prejudice and interracial interaction. Journal of personality and social psychology, 2002, roč. 82, č. 1, s. 62. ISSN 0022-3514.

EPSTEIN, Seymour. Integration of the cognitive and the psychodynamic unconscious. American Psychologist, 1994, roč. 49, č. 8, s. 709-709. ISSN 0003-066X.

EVANS, Jonathan St. B. T. a David E. OVER. Rationality and Reasoning. 1. vyd. Hove: Psychology Press, 1996. ISBN 0863774385.

FAZIO, Russel H. et al. On the automatic activation of attitudes. Journal of personality and social psychology, 1986, roč. 50, č. 2, s. 229-238. ISSN 0022-3514.

FAZIO, Russel H. et al. Variability in automatic activation as an unobstrusive measure of racial attitudes: A bona fide pipeline? Journal of personality and social psychology, 1995, roč. 69, č. 6, s. 1013. ISSN 0022-3514.

FISHER, Robert J. Social Desirability Bias and the Validity of Indirect Questioning. Journal of Consumer Research, 1993, roč. 20, č. 2, s. 303-315. ISSN 0093-5301.

FLERE, Sergej a Miran LAVRIČ. Is intrinsic religious orientation a culturally specific American Protestant concept? The fusion of intrinsic and extrinsic religious orientation among non-Protestants. European Journal of Social Psychology, 2008, roč. 38, č. 3, s. 521-530. ISSN 1099-0992.

FRANCIS, Leslie J. Measuring attitude towards Christianity during childhood and adolescence. Personality and Individual Differences, 1989, roč. 10, č. 6, s. 695-698. ISSN 0191-8869.

FRIESE, Malte, Wilhelm HOFMANN a Manfred SCHMITT. When and why do implicit measures predict behaviour? Empirical evidence for the moderating role of opportunity, motivation, and process reliance. European Review of Social Psychology, 2009, roč. 19, č. 1, s. 285-338. ISSN 1046-3283.

GAWRONSKI, Bertram, Etienne P. LEBEL a Kurt R. PETERS. What Do Implicit Measures Tell Us? Scrutinizing the Validity of Three Common Assumptions. Perspectives on psychological science, 2007, roč. 2, č. 2, s. 181-193. ISSN 1745-6924.

GAWRONSKI, Bertram a Rajees SRITHARAN. Formation, change, and contextualization of mental associations: Determinants and principles of variations in implicit measures. In GAWRONSKI, Bertram a Keith B. PAYNE (eds.). Handbook of implicit social cognition: measurement, theory, and applications. 1. vyd. New York: The Guilford Press, 2010, s. 216-240. ISBN 9781606236734.

GEERTZ, Clifford. The interpretation of cultures: selected essays. 1. vyd. New York: Basic Books, 1973. ISBN 9780465097197.

GERVAIS, Will M. a Ara NORENZAYAN. Like a camera in the sky? Thinking about God increases public self-awareness and socially desirable responding. Journal of Experimental Social Psychology, 2012, roč. 48, č. 1, s. 298-302. ISSN 0022-1031.

GERVAIS, Will M. a Joseph HENRICH. The Zeus Problem: Why Representational Content Biases Cannot Explain Faith in Gods. Journal of Cognition \& Culture, 2010, roč. 10, č. 3/4, s. 383-389. ISSN 15677095.

GERVAIS, Will M. a Ara NORENZAYAN. Analytic thinking promotes religious disbelief. Science, 2012, sv. 336, č. 6080, s. 493-496. ISSN 0036-8075.

GIBSON, James J. The theory of affordances. In SHAW, Robert a John BRANSFORD (eds.). Perceiving, Acting, and Knowing: Toward an Ecological Psychology. 1. vyd. Hillsdale, NJ: Lawrence Erlbaum, 1977, s. 67-82. ISBN 9780470990155.

GIBSON, Nicolas J. S. The experimental investigation of religious cognition. Unpublished doctoral dissertation. Cambridge, UK: University of Cambridge, 2005.

GIGERENZER, Gerd a Peter M. TODD. Simple Heuristics That Make Us Smart. 1. vyd. New York: Oxford University Press, 1999. ISBN 9780195143812. 
Tomáš Hampejs: Náboženství v laboratoři sociální implicitní kognice...

GOFFMAN, Erving. Všichni hrajeme divadlo: sebeprezentace v každodenním životě. Nakladatelství Studia Ypsilon, 1999. ISBN 9788090248243.

GORSUCH, Richard L. a Susan E. McPHERSON. Intrinsic/extrinsic measurement: I/E-revised and single-item scales. Journal for the Scientific Study of Religion, 1989, roč. 28, č. 3, s. 348-354. ISSN 0021-8294.

GREENWALD, Anthony G. a Mahzarin R. BANAJI. Implicit social cognition: attitudes, self-esteem, and stereotypes. Psychological review, 1995, roč. 102, č. 1, s. 4. ISSN 1939-1471.

GREENWALD, Anthony G., Debbie E. McGHEE a Jordan L. K. SCHWARTZ. Measuring individual differences in implicit cognition: the implicit association test. Journal of personality and social psychology, 1998, roč. 74, č. 6, s. 1464-1480. ISSN 0022-3514.

GRIMES, Ronald L. Performance theory and the study of ritual. ANTES, Peter, Armin W. GEERTZ a Randi R. WARNE (eds.). New Approaches to the Study of Religion. 1. vyd. Berlin: De Grutyer, 2004, s. 109-138. ISBN 9783110211719.

HAN, H. Anna et al. Malleability of attitudes or malleability of the IAT? Journal of experimental social psychology, 2010, roč. 46, č. 2, s. 286-298. ISSN 0022-1031.

HART, C. W. Faith Development Theory. In LEEMING, David A., Kathryn MADDEN a Stanton MARLAN (eds.). Encyclopedia of psychology and religion. 1. vyd. New York: Springer, 2009, s. 342-343. ISBN 9780387718019.

HELSEL, P. Faith. In LEEMING, David A., Kathryn MADDEN a Stanton MARLAN (eds.). Encyclopedia of psychology and religion. 1. vyd. New York: Springer, 2009, s. 341-342. ISBN 9780387718019.

HENRICH, Joseph, Steven J. HEINE a Ara NORENZAYAN. The weirdest people in the world. Behavioral and Brain Sciences, 2010, roč. 33, č. 2-3, s. 61-83. ISSN 0140-525X.

HILL, Peter C. Toward an attitude process model of religious experience. Journal for the Scientific Study of Religion, 1994, roč. 33, č. 4, s. 303-314. ISSN 0021-8294.

HILL, Peter C. a Kenneth I. PARGAMENT. Advances in the conceptualization and measurement of religion and spirituality: Implications for physical and mental health research. American Psychologist, 2003, roč. 58, č. 1, s. 64-74. ISSN 0003-066X.

HOFMANN, Wilhelm a Timothy D. WILSON. Consciousness, introspection, and the adaptive unconscious. In GAWRONSKI, Bertram a Keith B. PAYNE (eds.). Handbook of implicit social cognition: measurement, theory, and applications. 1. vyd. New York: The Guilford Press, 2010, s. 197-215. ISBN 9781606236734.

HOOD, Ralph W., Peter C. HILL a Bernard SPILKA. The Psychology of Religion: An Empirical Approach. 4. vyd. New York: The Guilford Press, 2009. ISBN 1606233033.

HOUWER DE, Jan. A structural analysis of indirect measures of attitudes. In MUSCH, Jochen a Karl C. KLAUER (eds.). The psychology of evaluation: Affective processes in cognition and emotion. 1. vyd. Mahwah, NJ: Lawrence Erlbaum Associates, 2003, s. 219-244. ISBN 9781410606853.

HOUWER DE, Jan et al. Implicit measures: A normative analysis and review. Psychological bulletin, 2009, roč. 135, č. 3, s. 347-368. ISSN 0033-2909.

INGOLD, Tim. The perception of the environment: essays on livelihood, dwelling and skill. 1. vyd. London: Routledge, 2000. ISBN 9780203466025.

INGOLD, Tim. From the transmission of representations to the education of attention. In WHITEHOUSE, Harvey (ed.). The debated mind: evolutionary psychology versus ethnography. 1. vyd. Oxford: Berg Publishers, 2001, s. 113-153. ISBN 9781859734278.

ITO, Tiffany A. Implicit Social Cognition: Insights from Social Neuroscience. In GAWRONSKI, Bertram a Keith B. PAYNE (eds.). Handbook of implicit social cognition: measurement, theory, and applications. 1. vyd. New York: The Guilford Press, 2010, s. 80-94. ISBN 9781606236734.

JAMES, William. The will to believe: and other essays in popular philosophy. [online] London: Longmans, Green, and co., 1896. Dostupné z <http://www.gutenberg.org/files/26659/26659-h/26659-h.htm> 
JENSEN, Jeppe S. Religion as the unintended product of brain functions in the 'standard cognitive science of religion model'. In STAUSBERG, Michael (ed.). Contemporary Theories of Religion: a critical companion. New York: Routledge, 2009, s. 129-155. ISBN 9780415463461.

JONG, Jonathan. Implicit Measures in the Experimental Psychology of Religion. In DAWES, Gregory W. a James MACLAURIN (eds.). A New Science of Religion. 1. vyd. New York: Routledge, 2013, s. 65-78. ISBN 9780415635851.

KAHNEMAN, Daniel. Thinking, fast and slow. 1. vyd. New York: Farrar, Straus and Giroux, 2011. ISBN 9780374275631.

KARPINSKI, Andrew a Ross B. STEINMAN. The Single Category Implicit Association Test as a Measure of Implicit Social Cognition. Journal of Personality and Social Psychology, 2006, roč. 91, č. 1, s. 16-32. ISSN 0022-3514.

KIERKEGAARD, Søren. Concluding Unscientific Postscript. 1. vyd. Princeton, NJ: Princeton University Press, 1968 (1846). ISBN 9780691019604.

KIERKEGAARD, Søren. Fear and Trembling. 1. vyd. Radford, VA: A\&D Publishing, 2008 (1843). ISBN 9781604593181.

LANE, Kristin A. et al. Understanding and using the implicit association test: IV - What we know (so far) about the method. In WITTENBRING, Bernd a Norbert SCHWARTZ (eds.). Implicit measures of attitudes. New York: Guilford Press, 2007, s. 59-102. ISBN 9781593854027.

MA-KELLAMS, Christine a Jim BLASCOVICH. Does "Science" Make You Moral? The Effects of Priming Science on Moral Judgments and Behavior. PLoS ONE, 2013, roč. 8, č. 3. ISSN 1932-6203.

MEIER, Brian P. et al. What's ,up“ with God? Vertical space as a representation of the divine. Journal of Personality and Social Psychology, 2007, roč. 93, č. 5, s. 699-710. ISSN 0022-3514.

MERCIER, Hugo a Dan SPERBER. Intuitive and reflective inferences. In EVANS, Jonathan St. B. T. a Keith FRANKISH (eds.). Two Minds: Dual Processes and Beyond. 1. vyd. Oxford: Oxford University Press, 2009, s. 149-170. ISBN 9780199230167.

MOORS, Agnes, Adriaan SPRUYT a Jan DE HOUWER. In search of a measure that qualifies as implicit: Recommendations based on a decompositional view of automaticity. In GAWRONSKI, Bertram a Keith B. PAYNE (eds.). Handbook of implicit social cognition: measurement, theory, and applications. 1. vyd. New York: The Guilford Press, 2010, s. 19 - 37. ISBN 9781606236734.

NORENZAYAN, Ara a Will M. GERVAIS. The origins of religious disbelief. Trends in cognitive sciences, 2013, roč. 17, č. 1, s. 20-25. ISSN 1879-307X.

NOSEK, Brian A. Implicit-Explicit Relations. Current Directions in Psychological Science, 2007, roč. 16, č. 2, s. 65-69. ISSN 1467-8721.

OLSON, Michael A. a Russel H. FAZIO. Relations Between Implicit Measures of Prejudice What Are We Measuring? Psychological Science, 2003, roč. 14, č. 6, s. 636-639. ISSN 1467-9280.

PAYNE, B. Keith a Bertram GAWRONSKI. A history of implicit social cognition: Where is it coming from? Where is it now? Where is it going. In GAWRONSKI, Bertram a Keith B. PAYNE (eds.). Handbook of implicit social cognition: measurement, theory, and applications. 1. vyd. New York: The Guilford Press, 2010, s. 1-15. ISBN 9781606236734.

PAYNE, Richard K. Cognitive theories of ritual and Buddhist practice: An examination of Ilkka Pyysiäinen's Theory. Pacific World: Journal of the Institute of Buddhist Studies, 2002, č. 4, s. 75-90. ISSN 0897-3644.

PYYSIÄINEN, Ilkka. True fiction: Philosophy and psychology of religious belief. Philosophical Psychology, 2003, roč. 16, č. 1, s. 109-125. ISSN 1465-394X.

PYYSIÄINEN, Ilkka. Intuitive and Explicit in Religious Thought. Journal of Cognition \& Culture, 2004, roč. 4, č. 1, s. 123-150. ISSN 15677095.

PYYSIÄINEN, Ilkka. Cognitive Science of Religion: State-of-the-Art. Journal for the Cognitive Science of Religion, 2013, roč. 1, č. 1, s. 5-28. ISSN 2049-7555. 
Tomáš Hampejs: Náboženství v laboratoři sociální implicitní kognice...

RUGG, Michael D. et al. Dissociation of the neural correlates of implicit and explicit memory. Nature, 1998, sv. 392, č. 6676, s. 595-597. ISSN 0028-0836.

SEKAQUQAPTEWA, Denise, Patrick VARGAS a William VON HIPPEL. A Practical Guide to Paper-and-Pencil Implicit Measures of Attitudes. In GAWRONSKI, Bertram a Keith B. PAYNE (eds.). Handbook of implicit social cognition: measurement, theory, and applications. 1. vyd. New York: The Guilford Press, 2010, s. 140-155. ISBN 9781606236734.

SHARIFF, Azim F., Adam B. COHEN a Ara NORENZAYAN. The Devil's Advocate: Secular Arguments Diminish both Implicit and Explicit Religious Belief. Journal of Cognition and Culture, 2008, roč. 8, č. 3, s. 417-423. ISSN 1568-5373.

SHARIFF, Azim F. a Ara NORENZAYAN. God Is Watching You: Priming God Concepts Increases Prosocial Behavior in an Anonymous Economic Game. Psychological Science, 2007, roč. 18, č. 9 , s. 803-809. ISSN 0956-7976, 1467-9280.

SCHACTER, Daniel L. Implicit memory: History and current status. Journal of experimental psychology: learning, memory, and cognition, 1987, roč. 13, č. 3, s. 501. ISSN 0278-7393.

SIGALL, Harold a Richard PAGE. Current stereotypes: A little fading, a little faking. Journal of Personality and Social Psychology, 1971, roč. 18, č. 2, s. 247-255. ISSN 0022-3514.

SMITH, Jonathan Z. Religion, religions, religious. In TAYLOR, Mark C. (ed.). Critical terms for religious studies. Chicago: University of Chicago Press, 1998, s. 269-284. ISBN 9780226791562.

SOSIS, Richard a Candace ALCORTA. Signaling, solidarity, and the sacred: The evolution of religious behavior. Evolutionary Anthropology: Issues, News, and Reviews, 2003, roč. 12, č. 6, s. 264-274. ISSN 10601538.

SPERBER, Dan. Explaining Culture: A Naturalistic Approach. Oxford, UK: Wiley-Blackwell, 1996. ISBN 9780631200451.

SPERBER, Dan. Intuitive and reflective beliefs. Mind \& Language, 1997, roč. 12, č. 1, s. 67-83. ISSN 1468-0017.

SQUIRE, Larry R. et al. Memory: organization of brain systems and cognition. In MAYER, David E. a Sylvan KORNBLUM (eds.). Attention and performance: Synergies in Experimental Psychology, Artificial Inteligence and Cognitive Neuroscience. 1. vyd. Cambridge, MA: MIT Press, 1993, s. 393-424. ISBN 0-262-13284-2.

STROOP, J. Ridley. Studies of interference in serial verbal reactions [online]. Doctoral dissertation. George Peabody College for Teachers. Dostupné z: $<$ http://psychcentral.com/classics/Stroop $>$

TEIGE-MOCIGEMBA, Sarah, Karl Christoph KLAUER a Jeffrey W. SHERMAN. Practical guide to Implicit Association Test and related tasks. In GAWRONSKI, Bertram a Keith B. PAYNE (eds.). Handbook of implicit social cognition: measurement, theory, and applications. New York: The Guilford Press, 2010, s. 117-139. ISBN 9781606236734.

WARRINGTON, Elizabeth K. a L. WEISKRANTZ. A study of learning and retention in amnesic patients. Neuropsychologia, 1968, roč. 6, č. 3, s. 283-291. ISSN 0028-3932.

WEGNER, Daniel M. The mind's best trick: how we experience conscious will. Trends in cognitive sciences, 2003, roč. 7, č. 2, s. 65-69. ISSN 1879-307X.

WHITEHOUSE, Harvey. Modes of Religiosity and the Cognitive Science of Religion. Method \& Theory in the Study of Religion, 2004, roč. 16, č. 3, s. 321-335. ISSN 09433058.

WILLIAMS, J. Mark G., Andrew MATHEWS a Colin MACLEOD. The emotional Stroop task and psychopathology. Psychological bulletin, 1996, roč. 120, č. 1, s. 3-24. ISSN 0033-2909.

WILSON, Deirdre a Dan SPERBER. Relevance theory. In WARD, Gregory a Laurence HORN (eds.). Handbook of pragmatics. Oxford: Blackwell, 2004, s. 607-632. ISBN 9781405129015.

WISDO, David. Kierkegaard on belief, faith, and explanation. International Journal for Philosophy of Religion, 1987, roč. 21, č. 2, s. 95-114. ISSN 0020-7047. 
SOCIÁLNÍ STUDIA 2/2013

YOSHIDA, Emiko et al. Not all automatic associations are created equal: How implicit normative evaluations are distinct from implicit attitudes and uniquely predict meaningful behaviour. Journal of Experimental Social Psychology, 2012, roč. 48, č. 3, s. 694-706. ISSN 0022-1031.

\section{Autor}

Tomáš Hampejs je doktorským studentem Ústavu religionistiky Filozofické fakulty Masarykovy univerzity $\mathrm{v}$ Brně. Jeho dizertační projekt se snaží experimentálně uchopit některé prvky náboženské víry a rituálu mezi kognitivní vědou o náboženství, sociální psychologií implicitní kognice a situačním jednání s ohledem na tzv. rozšířenou kognici.

Kontakt: tomas.hampejs@mail.muni.cz 